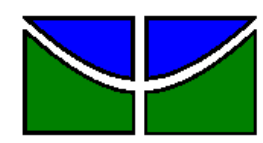

Universidade de Brasília

Faculdade de Economia, Administração e Contabilidade

Departamento de Administração

Curso de Graduação de Administração à Distância

JORGE MARINHO DA SILVA JUNIOR

\title{
DIAGNÓSTICO DA GESTÃO DE PROJETOS APÓS A IMPLANTAÇÃO DE GERÊNCIA DE PROJETOS DE TI: estudo na Diretoria de Tecnologia de um Banco Comercial
}

Brasília - DF 
JORGE MARINHO DA SILVA JUNIOR

\section{DIAGNÓSTICO DA GESTÃO DE PROJETOS APÓS A IMPLANTAÇÃO DE GERÊNCIA DE PROJETOS DE TI: estudo na Diretoria de Tecnologia de um Banco Comercial}

Monografia apresentada à Universidade de Brasília (UnB) como requisito parcial à obtenção do grau de Bacharel em Administração, na modalidade à distância, pela Universidade de Brasília (UnB).

Professora Supervisora: $\mathrm{Dr}^{\mathrm{a}}$. Josivania Silva Farias

Professor Orientador: Esp. Douglas Schneider de Fries

Brasília - DF

2011 
Silva Junior, Jorge Marinho da

Diagnóstico da Gestão de Projetos Após a Implantação de Gerência de Projetos de TI: Estudo na Diretoria de Tecnologia de um Banco Comercial / Jorge Marinho da Silva Junior. Brasília, 2011.

63 f.: il.

Monografia (bacharelado) - Universidade de Brasília, Departamento de Administração - EaD, 2011.

Orientador: Prof. Douglas Schneider de Fries, Departamento de Administração.

1. Gestão de Projetos. 2. Mudança Organizacional. 3. Estrutura Organizacional. 


\title{
RESUMO
}

\begin{abstract}
O trabalho tem como objetivo identificar quais são as dificuldades na gestão de projetos de Tecnologia da Informação quando introduzida na forma de atendimento das demandas da empresa. Para isso, foi realizada uma revisão na bibliografia sobre dificuldades na gestão de projetos e um estudo de caso em uma Gerência de Projetos na área de Tecnologia de um Banco Comercial. A pesquisa de campo foi realizada por comunicação, com a aplicação de um questionário diretamente aos respondentes, utilizando variáveis quantitativas para a análise dos resultados. Quatro grupos de problemas principais foram identificados na pesquisa bibliográfica e utilizados para organizar as questões no instrumento de pesquisa: organizacionais e da alta gerência, relacionados aos desenvolvedores, relacionados aos líderes de projeto e relacionados a terceiros. Observou-se que muitas dificuldades estão relacionadas à estrutura organizacional que a empresa adotou para trabalhar com a gestão por projetos. Os líderes de projeto, como peças-chave na condução dos mesmos ao sucesso, precisam de uma atuação mais eficiente e a capacitação dos mesmos pode ser um bom caminho a ser trilhado pela organização. A necessidade de patrocínio da alta gerência aos projetos também foi investigada e mostrou-se um ponto forte dentro da organização. O diagnóstico considerou também as variáveis cargo e tempo na área de tecnologia dos respondentes como forma de identificar a influência das mesmas.
\end{abstract}

Palavras-chave: Gestão de Projetos, Mudança Organizacional e Estrutura Organizacional. 


\section{LISTA DE ILUSTRAÇÔES}

Gráfico 1 - Dificuldades agrupadas por categorias. 


\section{LISTA DE ABREVIATURAS E SIGLAS}

TI - Tecnologia da informação

PMO - Project Management Offices

PERT - Program Evaluation and Review Technique

CPM - Critical Path Method

PMI - Project Management Institute

PIB - Produto Interno Bruto

PMP - Project Management Professional

DITEC - Diretoria de Tecnologia

UECS - Unidade de Estruturação e Construção de Soluções de TI

UOS - Unidade de Operação de Soluções de TI

GPP - Gerência de Portfólio e Projetos

PMBOK® - Project Management Body of Knowledge 


\section{LISTA DE QUADROS}

Quadro 1 - Fases do projeto $x$ áreas de conhecimento ….................................15

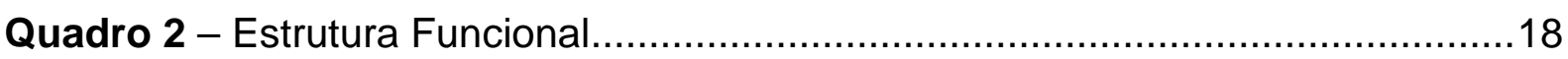

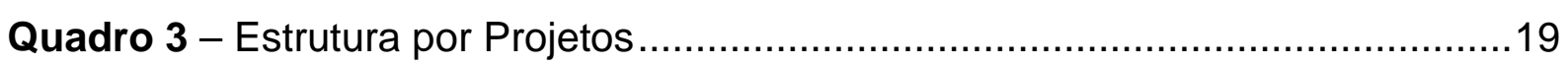

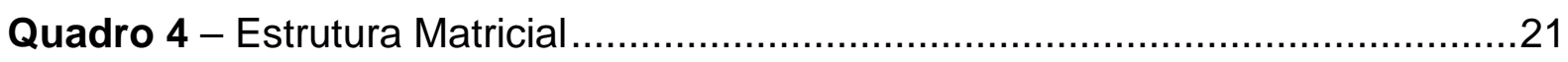

Quadro 5 - Agrupamento dos problemas por afinidade ............................................

Quadro 6 - Problemas organizacionais e da alta gerência .....................................33

Quadro 7 - Problemas relacionados aos líderes de projeto ....................................34

Quadro 8 - Problemas relacionados aos desenvolvedores .....................................36

Quadro 9 - Problemas relacionados a terceiros.................................................

Quadro 10 - Dificuldades agrupadas por categorias .........................................38 


\section{SUMÁRIO}

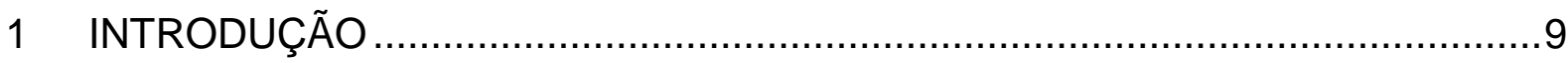

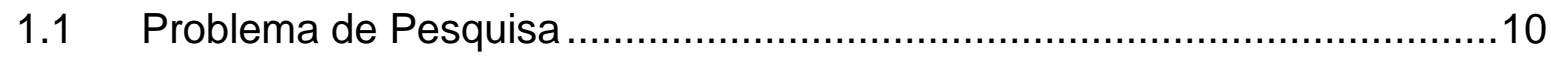

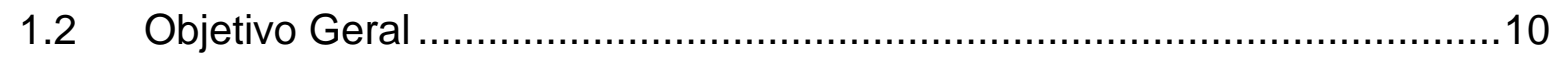

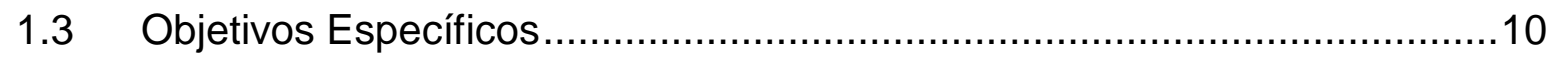

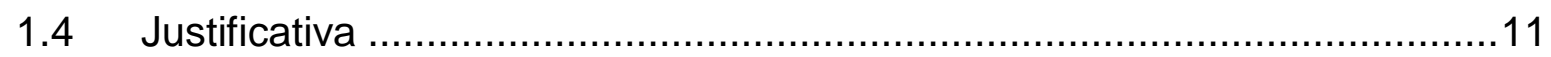

2 REFERENCIAL TEÓRICO ........................................................... 12

2.1 Histórico do Gerenciamento de Projetos............................................ 12

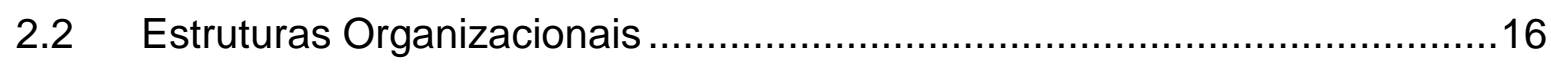

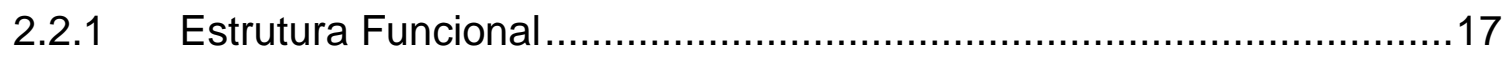

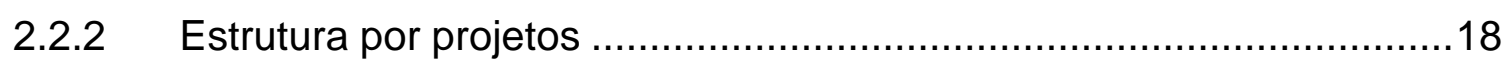

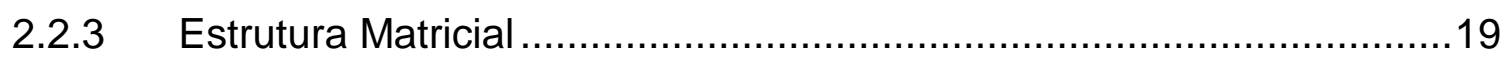

2.3 Problemas em Gerenciamento de Projetos ....................................21

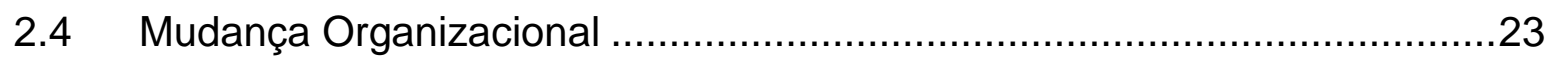

3 MÉTODOS E TÉCNICAS DE PESQUISA ..............................................26

3.1 Tipo e descrição geral da pesquisa...............................................26

3.2 Caracterização da organização, setor ou área do objeto de estudo ...........27

3.2.1 Visão Geral da Gestão por Projetos na TI do Banco Estudado ...........29

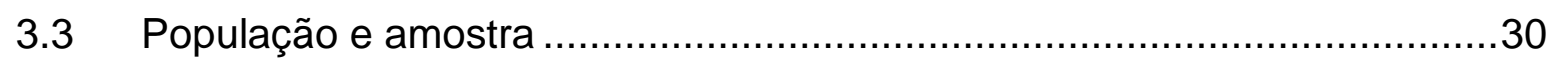

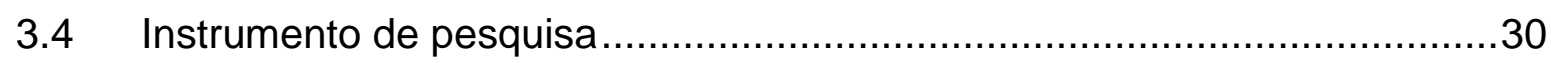

3.5 Procedimentos de coleta e de análise de dados...................................32

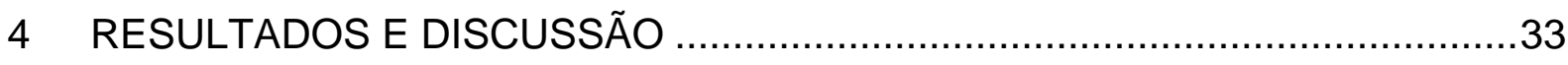

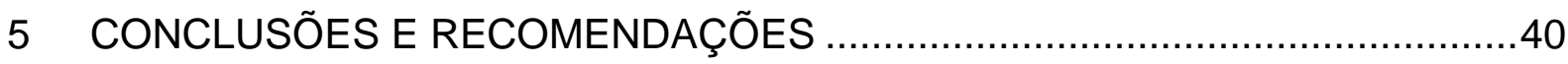

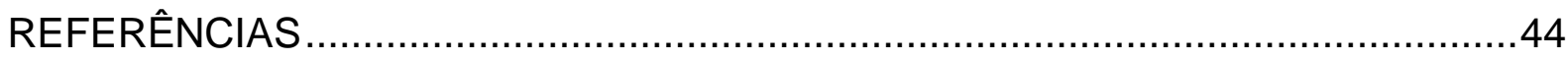

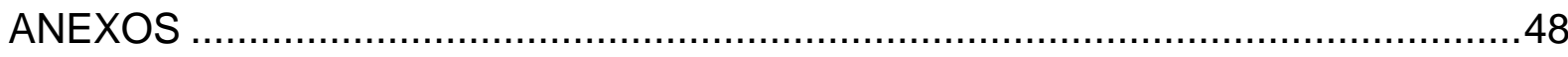

ANEXO 1 - Proposta de questionário:................................................48

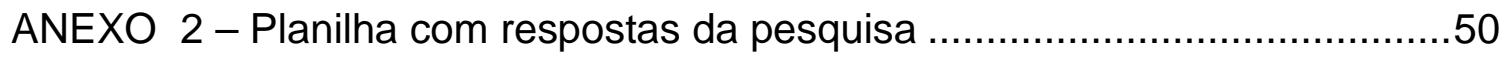

ANEXO 3 - Questionário de pesquisa ..............................................51

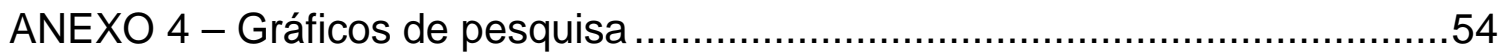

ANEXO 5 - Planilhas de cálculo ...........................................................60 


\section{INTRODUÇÃO}

As empresas de Tecnologia da Informação (TI), acompanhando uma tendência mundial, estão direcionando-se para uma forma de atendimento através de projetos. Segundo Giazzon (2005), o mercado de tecnologia evoluiu para a orientação a projetos. É uma tendência mundial o fim da exclusividade da mão-deobra alocada como prestação de serviço. O desenvolvimento de novos produtos em TI segue hoje o caminho adotado há tempos pelas empresas de engenharia: baseado em projetos (GIAZZON, 2005).

Hoje, o gerenciamento de projetos está muito fortalecido. As organizações sabem que precisam gerenciar projetos para obterem sucesso. O Project Management Institute (PMI) estima que aproximadamente $25 \%$ do PIB mundial é gasto em projetos e que cerca de 16,5 milhões de profissionais estão envolvidos diretamente com gerência de projetos no mundo. Este volume de projetos e as mudanças no cenário mundial, cada vez mais competitivo, geram a necessidade de resultados mais rápidos, com qualidade maior e custo menor (TORREÃO, 2005).

Gido e Clements (2007) identificam que os tipos mais comuns de estrutura organizacional com os quais as pessoas podem se organizar para trabalhar por projetos são: funcional, onde a autoridade do gerente de projetos é limitada e as pessoas não têm dedicação integral ao projeto; por projetos, onde os membros da equipe estão totalmente dedicados às atividades do projeto e o gerente tem autoridade funcional sobre os mesmos; matricial, uma estrutura que combina as características das duas anteriores.

As empresas têm criado estruturas organizacionais específicas para a gestão de projetos as quais se tornaram conhecidas no mundo corporativo como escritório de projetos e pela sigla em inglês PMO (Project Management Offices). Porém existem importantes resistências e obstáculos para a implantação do PMO. Atividades de apoio e controle são vistas como desperdício e as técnicas de gerenciamento de projetos como "burocratizantes". A gestão de projetos é uma das áreas de maior problema e na qual as empresas desejavam investir e melhorar suas práticas (BARBALHO et al, 2009). 
Muitas vezes a transição de uma forma de trabalho não direcionada a projetos para uma estrutura projetizada causa muitos desgastes e, até que o novo modelo esteja maduro, prejuízos para a empresa. $O$ presente trabalho pesquisará na literatura disponível casos correlatos já relatados e identificará os principais problemas que acontecem nesta transição por meio de uma pesquisa na área de $\mathrm{TI}$ de um Banco Comercial, realizando-se um diagnóstico da situação e análise dos resultados.

\subsection{Problema de Pesquisa}

Quais as dificuldades na gestão dos projetos em uma empresa que adotou esta forma de atendimento para as suas demandas?

\subsection{Objetivo Geral}

Analisar a percepção dos analistas da área de TI do Banco quanto à gestão de projetos após a introdução dessa forma de atendimento às demandas para a área de $\mathrm{TI}$, gerando um diagnóstico da situação.

\subsection{Objetivos Específicos}

- Pesquisar na bibliografia casos de implantação do gerenciamento de projetos e a influência desta mudança na gestão dos projetos.

- Obter a percepção dos analistas quanto aos fatores de sucesso para a gestão de projetos com a mudança da estrutura organizacional por meio de uma pesquisa na Diretoria de Tecnologia do Banco.

- Analisar o resultado da pesquisa identificando os pontos críticos e apresentar um diagnóstico da situação. 


\subsection{Justificativa}

O Banco Comercial objeto da pesquisa é um dos maiores da América Latina. Com a informatização dos seus processos operacionais, acompanhando as evoluções tecnológicas das últimas décadas, a dependência da tecnologia para a realização de negócios cresceu consideravelmente. O volume de demandas oriundas das áreas de negócio para a área de Tl, acompanhando este movimento, é crescente. Manter o método tradicional de atendimento tem se demonstrado ineficaz, pois a área de TI não tem capacidade de atender aos novos pedidos, sempre crescentes, nem à velocidade das mudanças. Ao mesmo tempo, não consegue demonstrar satisfatoriamente para as outras áreas do Banco, suas demandantes, onde a sua mão de obra está sendo empregada. A estrutura voltada para projetos poderá permitir um gerenciamento mais eficaz dos recursos, identificando-se prioridades alinhadas aos objetivos estratégicos da empresa, direcionando os recursos humanos limitados para as demandas realmente prioritárias.

Além disso, é preciso que os empreendimentos de TI que estão em andamento sejam acompanhados e vistos por toda a empresa, o que é extremamente prejudicado com a forma de atendimento tradicional. Como forma de atender esta demanda, a utilização de atendimento por projetos foi escolhida, porém, essa mudança não acontece na velocidade e qualidade adequada por conta de problemas que, se fossem corretamente identificados e tratados, poderiam aumentar a eficiência da Diretoria de Tecnologia e consequentemente de toda a empresa. 


\section{REFERENCIAL TEÓRICO}

\subsection{Histórico do Gerenciamento de Projetos}

Projetos são realizados desde os primórdios da civilização. O gerenciamento de projetos é algo que é realizado pelo homem desde a antiguidade (BERKUN, 2008). A partir do final do século XIX, onde a Revolução Industrial desempenhou importante papel no desenvolvimento do capitalismo industrial, as empresas passaram a exigir mais gerenciamento e controle em suas tarefas (TORREÃO, 2005).

As organizações se deparam com processos mais complexos, tanto em número de recursos humanos quanto em controle de insumos para a realização de um conjunto de atividades que envolviam, além disso, um número grande de intervenientes externos. Iniciam-se, então, os primeiros conceitos de gestão de projetos através dos trabalhos de Frederick Taylor e, posteriormente, de seu sócio Henry Gantt (TORREÃO, 2005).

Taylor aplicou o raciocínio científico para mostrar que o trabalho pode ser analisado e melhorado, focando em suas partes elementares. Gantt construiu diagramas com barras de tarefas e marcos, que esboçam a sequência e a duração de todas as tarefas em um processo. Este diagrama mostrou-se ser uma importante ferramenta para os gerentes e só sofreu modificação nos anos 90 com a introdução de linhas de ligação entre as tarefas (TORREÃO, 2005).

Após a II Guerra Mundial, a complexidade dos projetos demandou novas estruturas organizacionais. Complexos Diagramas de Rede, chamados de Gráficos de PERT (Program Evaluation and Review Technique) e o método de Caminho Crítico (Critical Path Method - CPM) foram introduzidos, oferecendo aos gerentes maior controle sobre os projetos (TORREÃO, 2005).

No início dos anos 60, o gerenciamento de projetos foi formalizado como ciência e, em 1969, no auge dos projetos espaciais da NASA, um grupo de cinco profissionais de gestão de projetos, da Philadelphia, Pennsylvania, nos EUA, se reuniu para discutir as melhores práticas e Jim Snyder fundou o Project Management Institute - PMI (EUA). O PMI é a maior instituição internacional dedicada à disseminação do conhecimento e ao aprimoramento das atividades de 
gestão profissional de projetos atualmente (TORREÃO, 2005). Trata-se de uma organização que congrega profissionais de gerenciamento de projetos que buscam desenvolver e divulgar conhecimentos que permitam aos gerentes de projetos aperfeiçoarem o seu trabalho (DINSMORE; SILVEIRA NETO; 2009).

Segundo o Project Management Institute, PMI (2000) um projeto pode ser definido como um esforço temporário para criar um produto ou serviço único, e o gerenciamento de projetos pode ser definido como a arte de coordenar atividades com o objetivo de atingir as expectativas dos stakeholders. Projetos são blocos de construção no desenvolvimento e na execução de estratégias organizacionais, e gerenciar projetos é gerenciar mudanças (FAJARDO; ARMANDO, 2008).

O PMI possui uma publicação denominada "Conjunto de conhecimentos do gerenciamento de projetos" (Guia PMBOK® - Project Management Body of Knowledge) que apresenta um conjunto de conhecimentos amplamente reconhecido como boa prática, aplicáveis à maioria dos projetos na maior parte do tempo, categorizados em nove áreas: escopo, tempo, custo, qualidade, comunicação, recursos humanos, aquisições, risco e integração (DINSMORE; SILVEIRA NETO; 2009). Os processos relacionados a estes conhecimentos são organizados em cinco grupos ao longo do ciclo de vida do projeto: iniciação, planejamento, execução, monitoramento e controle, encerramento. Editado na forma de livro, o Guia PMBOK está atualmente na quarta edição de 2008 e traduzido oficialmente para diversos idiomas, inclusive o português do Brasil. As edições anteriores foram publicadas nos anos de 1996, 2000 e 2004 (PMI, 2008).

Dinsmore e Silveira Neto (2009) explicam que os cinco grupos de processos do gerenciamento de projetos compõem o que é chamado de ciclo de vida do projeto, que consiste nas diversas fases do mesmo:

- iniciação: identificação de necessidades, análise de viabilidade, procura de alternativas, desenvolvimento de orçamento e cronograma iniciais, preparação da proposta;

- planejamento: programação dos recurso humanos, materiais e financeiros, preparação do plano para aprovação da execução;

- execução: cumprimento das atividades planejadas;

- monitoramento e controle: acompanhar as atividades programadas de forma a cumprir o plano e modificá-lo no que for necessário; 
- encerramento: conclusão das atividades do projeto, verificações de qualidade, realocação dos membros da equipe.

Para que o gerente de projeto possa cumprir os processos do ciclo de vida, as nove áreas precisam ser gerenciadas, sendo que as três primeiras a serem estudadas pelo PMI formam o que se chama de Triângulo Sagrado do gerenciamento de projetos: prazos, custos e qualidade. (DINSMORE; SILVEIRA NETO; 2009). As nove áreas de conhecimento da Gerência de Projetos são descritas no PMBOK em capítulos. Soares e Tibo (2000, p. 6), através do PMI de Minas Gerais publicaram uma tradução livre do PMBOK que descreve estas áreas:

O Capítulo 4, Gerência da Integração do Projeto, descreve os processos necessários para assegurar que os diversos elementos do projeto sejam adequadamente coordenados. Ele é composto pelo desenvolvimento do plano do projeto, execução do plano do projeto e controle geral de mudanças.

O Capítulo 5, Gerência do Escopo do Projeto, descreve os processos necessários para assegurar que o projeto contemple todo o trabalho requerido, e nada mais que o trabalho requerido, para completar o projeto com sucesso. Ele é composto pela iniciação, planejamento do escopo, detalhamento do escopo, verificação do escopo e controle de mudanças do escopo.

O Capítulo 6, Gerência do Tempo do Projeto, descreve os processos necessários para assegurar que o projeto termine dentro do prazo previsto. Ele é composto pela definição das atividades, seqüenciamento das atividades, estimativa da duração das atividades, desenvolvimento do cronograma e controle do cronograma.

o Capítulo 7, Gerência do Custo do Projeto, descreve os processos necessários para assegurar que o projeto seja completado dentro do orçamento previsto. Ele é composto pelo planejamento dos recursos, estimativa dos custos, orçamento dos custos e controle dos custos.

O Capítulo 8, Gerência da Qualidade do Projeto, descreve os processos necessários para assegurar que as necessidades que originaram 0 desenvolvimento do projeto serão satisfeitas. Ele é composto pelo planejamento da qualidade, garantia da qualidade e controle da qualidade.

O Capítulo 9, Gerência dos Recursos Humanos do Projeto, descreve os processos necessários para proporcionar a melhor utilização das pessoas envolvidas no projeto. Ele é composto pelo planejamento organizacional, montagem da equipe e desenvolvimento da equipe.

O Capítulo 10, Gerência das Comunicações do Projeto, descreve os processos necessários para assegurar que a geração, captura, distribuição, armazenamento e pronta apresentação das informações do projeto sejam feitas de forma adequada e no tempo certo. Ele é composto pelo planejamento das comunicações, distribuição das informações, relato de desempenho e encerramento administrativo.

O Capítulo 11, Gerência dos Riscos do Projeto, descreve os processos que dizem respeito à identificação, análise e resposta a riscos do projeto. Ele é composto pela identificação dos riscos, quantificação dos riscos, desenvolvimento das respostas aos riscos e controle das respostas aos riscos.

O Capítulo 12, Gerência das Aquisições do Projeto, descreve os processos necessários para a aquisição de mercadorias e serviços fora da organização que desenvolve o projeto. Ele é composto pelo planejamento 
das aquisições, preparação das aquisições, obtenção de propostas, seleção de fornecedores, administração dos contratos e encerramento do contrato (SOARES; TIBO, 2000, p.6).

O Quadro 1 mostra a relação entre as fases do projeto e os processos das áreas de conhecimento descritos pelo PMBOK.

\begin{tabular}{|c|c|c|c|c|c|}
\hline & Iniciação & Planejamento & Execução & $\begin{array}{l}\text { Monitoramento } \\
\text { e Controle }\end{array}$ & Encerramento \\
\hline $\begin{array}{l}\text { Gerência da } \\
\text { Integração do } \\
\text { Projeto }\end{array}$ & & $\begin{array}{l}\text { 4.1. Desenvolvimento } \\
\text { do plano do projeto }\end{array}$ & $\begin{array}{l}\text { 4.2.Execução do } \\
\text { plano do projeto }\end{array}$ & $\begin{array}{l}\text { 4.3.Controle geral } \\
\text { de mudanças }\end{array}$ & \\
\hline $\begin{array}{l}\text { Gerência do } \\
\text { Escopo do } \\
\text { Projeto }\end{array}$ & 5.1.Iniciação & $\begin{array}{l}\text { 5.2.Planejamento do } \\
\text { escopo } \\
\text { 5.3.Detalhamento do } \\
\text { escopo }\end{array}$ & & $\begin{array}{l}\text { 5.4.Verificação do } \\
\text { escopo } \\
\text { 5.5.Controle de } \\
\text { mudanças do } \\
\text { escopo }\end{array}$ & \\
\hline $\begin{array}{l}\text { Gerência do } \\
\text { Tempo do } \\
\text { Projeto }\end{array}$ & & $\begin{array}{l}\text { 6.1.Definição das } \\
\text { atividades } \\
\text { 6.2.Sequenciamento } \\
\text { das atividades } \\
\text { 6.3. Estimativa de } \\
\text { duração das } \\
\text { atividades } \\
\text { 6.4. Desenvolvimento } \\
\text { do cronograma }\end{array}$ & & $\begin{array}{l}\text { 6.5.Controle do } \\
\text { cronograma }\end{array}$ & \\
\hline $\begin{array}{l}\text { Gerência do } \\
\text { Custo do } \\
\text { Projeto }\end{array}$ & & $\begin{array}{l}\text { 7.1.Planejamento dos } \\
\text { recursos } \\
\text { 7.2. Estimativa dos } \\
\text { custos } \\
\begin{array}{c}\text { 7.3. Orçamento dos } \\
\text { custos }\end{array}\end{array}$ & & $\begin{array}{l}\text { 7.4. Controle dos } \\
\text { custos }\end{array}$ & \\
\hline $\begin{array}{c}\text { Gerência da } \\
\text { Qualidade do } \\
\text { Projeto } \\
\end{array}$ & & $\begin{array}{l}\text { 8.1.Planejamento da } \\
\text { qualidade }\end{array}$ & $\begin{array}{l}\text { 8.2.Garantia da } \\
\text { qualidade }\end{array}$ & $\begin{array}{l}\text { 8.3.Controle da } \\
\text { qualidade }\end{array}$ & \\
\hline $\begin{array}{c}\text { Gerência dos } \\
\text { Recursos } \\
\text { Humanos do } \\
\text { Projeto } \\
\end{array}$ & & $\begin{array}{c}\text { 9.1.Planejamento } \\
\text { organizacional } \\
\text { 9.2.Montagem da } \\
\text { equipe }\end{array}$ & $\begin{array}{l}\text { 9.3.Desenvolvim } \\
\text { ento da equipe }\end{array}$ & & \\
\hline $\begin{array}{c}\text { Gerência das } \\
\text { Comunicações } \\
\text { do Projeto }\end{array}$ & & $\begin{array}{l}\text { 10.1.Planejamento } \\
\text { das comunicações }\end{array}$ & $\begin{array}{l}\text { 10.2.Distribuição } \\
\text { das informações }\end{array}$ & $\begin{array}{l}\text { 10.3. Relato de } \\
\text { desempenho }\end{array}$ & $\begin{array}{c}\begin{array}{c}\text { 10.4. Encerrame } \\
\text { nto }\end{array} \\
\text { administrativo }\end{array}$ \\
\hline $\begin{array}{l}\text { Gerência dos } \\
\text { Riscos do } \\
\text { Projeto }\end{array}$ & & $\begin{array}{l}\text { 11.1. Identificação dos } \\
\text { riscos } \\
\text { 11.2. Quantificação } \\
\text { dos riscos } \\
\text { 11.3. Desenvolvimento } \\
\text { das respostas aos } \\
\text { riscos }\end{array}$ & & $\begin{array}{l}\text { 11.4. Controle das } \\
\text { respostas aos } \\
\text { riscos }\end{array}$ & \\
\hline $\begin{array}{c}\text { Gerência das } \\
\text { Aquisições do } \\
\text { Projeto }\end{array}$ & & $\begin{array}{l}\text { 12.1.Planejamento } \\
\text { das aquisições } \\
\text { 12.2.Preparação das } \\
\text { aquisições }\end{array}$ & $\begin{array}{c}\text { 12.3.Obtenção } \\
\text { de propostas } \\
\text { 12.4.Seleção de } \\
\text { fornecedores } \\
\text { 12.5.Administraç } \\
\text { ão dos contratos }\end{array}$ & $\begin{array}{l}\text { 12.6. Encerramento } \\
\text { dos contratos }\end{array}$ & \\
\hline
\end{tabular}

Quadro 1 - Fases do projeto x áreas de conhecimento

Fonte: Adaptado de Perrelli (2004)

Os projetos tornaram-se um importante instrumento de desenvolvimento e transformação para as organizações. A disciplina de gerência de projetos vem 
ganhando importância e destaque dentro da administração sendo necessário o desenvolvimento pelas empresas de competências organizacionais em gerenciamento de projetos. Junto a esta necessidade, agrega-se a dificuldade das empresas adaptarem os seus processos ao gerenciamento de projetos (BOUER; CARVALHO, 2005).

\subsection{Estruturas Organizacionais}

Segundo Cury (2006), a estrutura é o arranjo dos elementos constitutivos de uma organização, ou seja, é a forma mediante a qual estão integrados e se apresentam os elementos componentes de uma empresa.

A palavra estrutura pode ser apresentada considerando duas definições: as partes físicas da empresa, como edifícios e unidades de trabalho, a localização de estabelecimento; ou como os elementos de trabalho, sistema de organização, organização do trabalho, processo produtivo e organização da produção (CURY, 2006).

Para a função de Organização e Métodos - O\&M, a estrutura compreende a disposição das diversas unidades que compõem a empresa e a relação entre superiores e subordinados (CURY, 2006). Patah e Carvalho (2002) e Gido e Clements (2007), identificam como as estruturas mais comuns utilizadas para trabalhar por projetos: a funcional, por projetos e matricial. A estrutura funcional fundamenta-se na técnica e, portanto, preocupa-se com o desenvolvimento e capacitação dos valores técnicos. A estrutura por projetos tem um objetivo bem definido e fundamenta-se no produto, preocupando-se em atender ao cliente (CURY, 2006).

$\mathrm{Na}$ organização funcional os grupos são compostos por pessoas que realizam a mesma função ou compartilham das mesmas habilidades, onde cada área concentra-se em realizar suas próprias atividades. A equipe do projeto pode ser formada por pessoas de várias áreas, que continuam a desempenhar suas funções regulares e atendem ao projeto em tempo parcial ou ser de uma única área. $\mathrm{O}$ gerente do projeto não possui autoridade administrativa sobre os membros do projeto, que continuam hierarquicamente subordinados aos gerentes de sua equipe (GIDO, J; CLEMENTS, J.P., 2007). 
$\mathrm{Na}$ estrutura organizacional por projetos são formadas equipes multidisciplinares onde todos os recursos dedicam-se exclusivamente às atividades de um projeto. Terminado o projeto a equipe se desfaz, sendo os seus membros designados para outros projetos ou dispensados. O gerente de projeto detém autoridade técnica e administrativa sobre todos os membros da equipe (GIDO, J; CLEMENTS, J.P., 2007).

A estrutura matricial é híbrida - uma mistura das estruturas organizacionais funcionais e por projetos. O gestor do projeto é o responsável pelos resultados do projeto, enquanto os gerentes funcionais são responsáveis por fornecer os recursos necessários para atingir os resultados. Os membros da equipe podem ser alocados em tempo integral ou parcial ao projeto, sendo que existe possibilidade de mobilidade dessas pessoas, dependendo do andamento do projeto. Cada participante de uma equipe de projeto tem uma dualidade de relações hierárquicas, o que pode causar conflito e ansiedade. É importante que estejam bem delineadas as responsabilidades pela gestão do projeto e pela gestão funcional (GIDO, J; CLEMENTS, J.P., 2007).

\subsubsection{Estrutura Funcional}

Cury (2006) classifica a estrutura com base em função como uma estrutura moderna, conceituada como aquela em que as atividades análogas, interdependentes, que se encadeiam num propósito dominante na empresa, são agrupadas em um órgão específico. Cada função principal se interessa por seus

próprios objetivos imediatos, desenvolvendo a capacidade e especialização do pessoal naquela função.

Patah e Carvalho (2002) identificam que a realização de um projeto em uma empresa com estrutura funcional acontece dentro de um dos departamentos técnicos da empresa e o gerente funcional deste departamento passa a ser o responsável pelo projeto. Já Gido e Clements (2007) identificam que os projetos podem envolver pessoas de vários departamentos, mas as mesmas continuam vinculadas funcionalmente aos seus gerentes e dedicam-se ao projeto apenas em tempo parcial. Uma empresa com uma estrutura funcional normalmente realiza desenvolvimento de projetos internos, já que esse tipo de organização não possui 
gestores designados para conduzir projetos financiados por clientes externos (GIDO, J; CLEMENTS, J.P., 2007).

Patah e Carvalho (2002) apontam as vantagens e desvantagens da utilização desta estrutura para projetos, descritos no Quadro 2.

\begin{tabular}{|c|c|}
\hline Vantagens & Desvantagens \\
\hline $\begin{array}{l}\text { - } \quad \text { existe uma grande flexibilidade no } \\
\text { uso dos recursos humanos } \\
\text { necessários ao projeto; } \\
\text { - } \quad \text { especialistas em determinado } \\
\text { assunto podem ser utilizados em } \\
\text { diferentes projetos; } \\
\text { - os especialistas de um mesmo } \\
\text { departamento podem ser facilmente } \\
\text { reunidos para compartilhar } \\
\text { conhecimentos e experiências; } \\
\text { o departamento funcional é a base } \\
\text { para a continuidade do conhecimento } \\
\text { tecnológico, quando um indivíduo } \\
\text { deixa o projeto ou mesmo a } \\
\text { empresa; } \\
\text { o departamento funcional } \\
\text { proporciona um caminho natural para } \\
\text { o crescimento dos indivíduos cuja } \\
\text { especialidade está na área funcional. }\end{array}$ & $\begin{array}{l}\text { - } \quad \text { o cliente não é o foco das atividades } \\
\text { do departamento que gerencia o } \\
\text { projeto; } \\
\text { - } \quad \text { o departamento funcional tende a ser } \\
\text { orientado em direção às suas } \\
\text { atividades particulares; } \\
\text { - } \quad \text { a responsabilidade total do projeto } \\
\text { não é delegada a nenhum } \\
\text { funcionário em específico; } \\
\text { - } \quad \text { as respostas às necessidades dos } \\
\text { clientes são lentas; } \\
\text { - existe uma tendência de subestimar } \\
\text { o projeto; } \\
\text { - a motivação das pessoas alocadas } \\
\text { no gerenciamento do projeto tende a } \\
\text { ser pequena em relação ao mesmo. }\end{array}$ \\
\hline
\end{tabular}

Quadro 2 - Estrutura Funcional

Fonte: Adaptado de Patah e Carvalho (2002)

\subsubsection{Estrutura por projetos}

$\mathrm{Na}$ organização por projetos, todos os recursos necessários para realizar cada projeto são designados para trabalho em tempo integral. Um gestor em tempo integral tem total autoridade administrativa e de projeto sobre a sua equipe. A organização por projetos é estruturada para ficar altamente focada no objetivo do projeto e nas necessidades do cliente. A estrutura do projeto é de natureza temporária, uma das características do mesmo, e quando o projeto é concluído os seus membros podem ser designados para outros projetos ou serem dispensados (GIDO, J; CLEMENTS, J.P., 2007). 
Cury (2006) apresenta os pressupostos que levam as organizações à adoção da estrutura com base em projeto:

- Estão engajadas em planejar e construir grandes fábricas ou maquinaria pesada, segundo especificações de clientes;

- Dependem das inovações dos produtos, dado que os fabricados se tornam obsoletos em pouco tempo;

- Os produtos/projetos são tecnicamente complexos, demandando uma grande dose de trabalho de desenvolvimento, que deve ser feito por certo número de diferentes especialistas técnicos;

- Os produtos/projetos devem ser fabricados dentro de rígidos cronogramas, para satisfazer às especificações dos clientes ou à procura de mercado (CURY, A., 2006, pag. 250).

Patah e Carvalho (2002) apontam as vantagens e desvantagens da utilização desta estrutura para projetos, descritos no Quadro 3.

\begin{tabular}{|c|c|}
\hline Vantagens & Desvantagens \\
\hline $\begin{array}{l}\text { - } \quad \text { gerente de projeto tem total } \\
\text { autoridade sobre o projeto; } \\
\text { - } \quad \text { todos os membros do projeto } \\
\text { encontram-se sob a responsabilidade } \\
\text { do gerente do projeto; } \\
\text { - } \quad \text { as comunicações são facilitadas em } \\
\text { comparação à estrutura funcional; } \\
\text { - os membros do time do projeto } \\
\text { possuem uma forte identidade } \\
\text { própria e, com isso, tendem a } \\
\text { desenvolver um alto nível de } \\
\text { comprometimento com o projeto; } \\
\text { - a possibilidade de se tomar decisões } \\
\text { rápidas é maior; } \\
\text { - existe uma unidade de comando } \\
\text { dentro do projeto; } \\
\text { estruturas projetizadas são } \\
\text { estruturalmente simples e flexíveis, e } \\
\text { relativamente fáceis de se } \\
\text { compreender e implementar. }\end{array}$ & 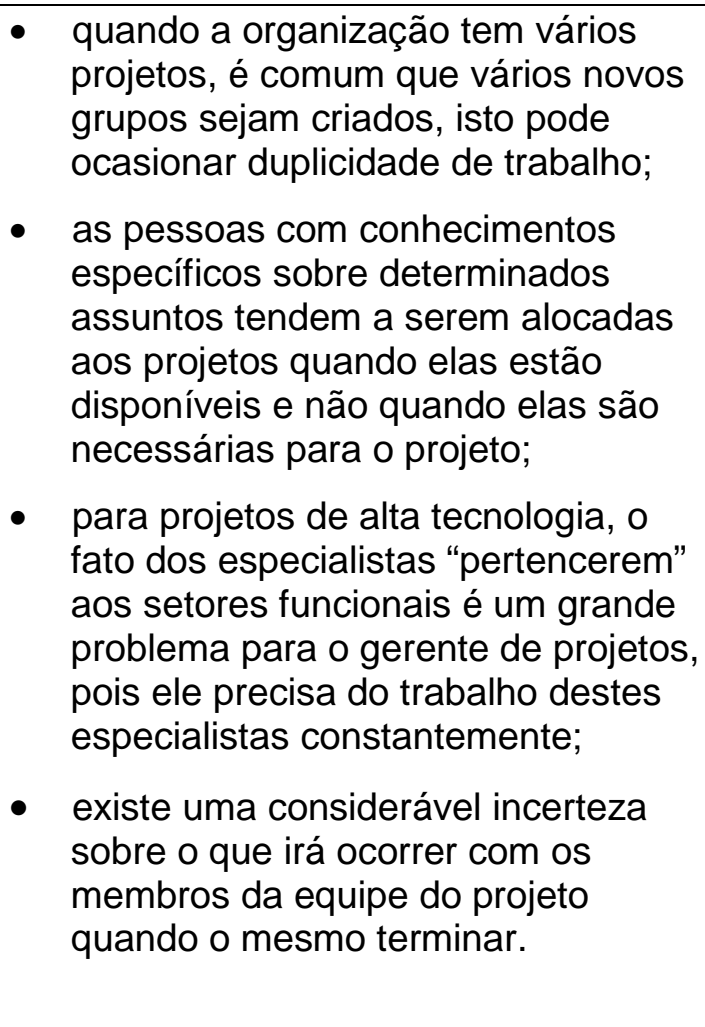 \\
\hline
\end{tabular}

Quadro 3 - Estrutura por Projetos

Fonte: Adaptado de Patah e Carvalho (2002)

\subsubsection{Estrutura Matricial}

Trata-se de uma estrutura híbrida que combina e estrutura funcional e a por projetos (GIDO; CLEMENTS; 2007). O gerente de projeto seleciona as pessoas que 
participarão do mesmo, mas elas continuam em seus departamentos vinculados ao seu gerente funcional. Ao término do projeto elas permanecem em seu departamento realizando as atividades do mesmo (PATAH; CARVALHO; 2002).

A estrutura matricial mantém o foco no cliente e no projeto, que são característicos da estrutura por projetos, mas é capaz de reter a experiência funcional da estrutura funcional. Existe uma grande flexibilidade na alocação das pessoas que varia de acordo com a necessidade de cada projeto. Algumas podem ser designadas para um projeto durante toda a sua duração; outras podem trabalhar só em uma parte ou entrar e sair no decorrer do projeto. Não é raro que uma pessoa de uma área funcional seja alocada meio período a vários projetos (GIDO; CLEMENTS; 2007).

Neste tipo de estrutura há necessidade de uma definição clara dos papéis, responsabilidades e autoridade de cada um dos atores. É fundamental especificar a quem os membros da equipe se reportam, já que existe uma dualidade de comando. As responsabilidades pela gestão do projeto e pela gestão funcional devem estar bem delineadas em uma organização matricial (CURY, A., 20006) (GIDO; CLEMENTS; 2007).

Patah e Carvalho (2002) identificam que a estrutura matricial pode apresentar-se de três formas. A primeira é a matricial fraca, onde os gerentes funcionais têm maior poder sobre os recursos que os gerentes de projeto. Neste tipo de estrutura o papel do gerente de projetos é mais o de um coordenador ou facilitador do que gerente de projetos propriamente dito (PMI, 2008). A segunda a matricial forte, onde os gerentes de projetos têm maior poder sobre as pessoas que os gerentes funcionais. A terceira a matricial equilibrada, onde os gerentes funcionais e de projetos possuem o mesmo nível de influência sobre o trabalho das pessoas que o executam. No Quadro quatro são descritas as vantagens e desvantagens desta estrutura. 


\begin{tabular}{|c|c|}
\hline Vantagens & Desvantagens \\
\hline $\begin{array}{l}\text { - } \quad \text { existe um responsável pelo projeto } \\
\text { como um todo: o gerente do projeto; } \\
\text { - devido ao fato do projeto estar } \\
\text { distribuído ao longo das divisões da } \\
\text { empresa, ele pode utilizar toda a } \\
\text { capacidade técnica da mesma; } \\
\text { - existe uma ansiedade menor sobre o } \\
\text { que irá ocorrer com as pessoas } \\
\text { envolvidas com o projeto, ao fim do } \\
\text { mesmo; } \\
\text { - as respostas às necessidades dos } \\
\text { clientes são rápidas; } \\
\text { - a estrutura matricial é flexível; } \\
\text { o projeto possui representantes das } \\
\text { unidades administrativas da } \\
\text { empresa; } \\
\text { devido ao fato de, normalmente, } \\
\text { ocorrerem vários projetos } \\
\text { simultaneamente nas empresas, a } \\
\text { estrutura matricial permite uma maior } \\
\text { otimização do uso dos recursos da } \\
\text { empresa. }\end{array}$ & $\begin{array}{l}\text { - } \quad \text { podem existir dúvidas quanto à } \\
\text { responsabilidade pela tomada de } \\
\text { uma decisão dentro do projeto, isto } \\
\text { pode atrasar a realização do mesmo; } \\
\text { - } \quad \text { os diferentes gerentes de projeto } \\
\text { podem "competir" pelos recursos } \\
\text { técnicos disponíveis na empresa, } \\
\text { fazendo com que o uso dos mesmos } \\
\text { deixe de ser realizado da melhor } \\
\text { maneira possível; } \\
\text { - é necessário que o gerente de } \\
\text { projetos possua uma habilidade } \\
\text { especial em negociar recursos com } \\
\text { os gerentes funcionais; } \\
\text { - estrutura matricial viola o princípio } \\
\text { de gerenciamento da unidade de } \\
\text { comando: os funcionários da } \\
\text { empresa possuem dois chefes, o } \\
\text { gerente do projeto e o gerente } \\
\text { funcional. }\end{array}$ \\
\hline
\end{tabular}

Quadro 4 - Estrutura Matricial

Fonte: Adaptado de Patah e Carvalho (2002)

\subsection{Problemas em Gerenciamento de Projetos}

Patah e Carvalho (2002) realizaram um trabalho, apresentado no XXII Encontro Nacional de Engenharia de Produção, em Curitiba - PR, de 23 a 25 de outubro de 2002, com o objetivo de identificar os critérios que direcionam a escolha da estrutura organizacional para o gerenciamento de projetos de uma empresa, bem como compará-los com os utilizados na prática pelas empresas que eles estudaram. O estudo foi realizado em cinco diferentes empresas atuantes no mercado brasileiro de telecomunicações.

As empresas pesquisadas por Patah e Carvalho (2002) possuem estruturas para gerenciamento de projetos que poderiam ser classificadas como matriciais fracas, apresentando similaridade com a situação da empresa estudada neste trabalho que se utiliza deste mesmo tipo de estrutura organizacional em seus 
projetos. $\mathrm{Na}$ análise dos resultados de sua pesquisa, Patah e Carvalho (2002) identificaram os seguintes fatores que causam a maioria dos problemas nos projetos: grande dependência de terceiros, falta de recursos humanos, falta de comprometimento das pessoas envolvidas, falta de agilidade e pró-atividade, dimensionamento errado do grupo de projeto, falta de experiência dos integrantes do projeto, falta de apoio dos níveis hierárquicos superiores, falta de clareza na definição de contrato com fornecedores e subfornecedores, problemas de logística, prazo insuficiente para a implantação do projeto, falta de planejamento adequado e capacitação dos gerentes de projeto insuficiente.

A falta de uma estrutura organizacional de projetos, ou até mesmo a utilização de uma estrutura inadequada, podem contribuir para a ineficiência na realização dos projetos (FAJARDO; ARMANDO, 2008). Quando a organização trabalha em uma estrutura funcional os conflitos internos são constantes, principalmente quando o projeto permeia várias áreas funcionais, pois os líderes de projeto não têm poderes formalmente instituídos sobre a equipe do projeto. A utilização de uma estrutura matricial proporciona um deslocamento dos membros que participam do projeto durante a duração do mesmo e desta forma, o líder de projeto tem mais autoridade sobre a equipe embora de forma compartilhada com 0 gerente funcional (LODI, 1970).

A estrutura por projetos consiste em uma organização temporária exclusivamente dedicada à execução de um projeto, com o gerente de projeto sendo o único superior hierárquico da equipe, que estará totalmente dedicada ao projeto (FAJARDO; ARMANDO, 2008). Porém, a mudança de estrutura pode não ser decisiva para minimizar os conflitos se, junto com ela, não acontecer uma alteração na forma como os colaboradores enxergam os benefícios de uma nova forma de trabalho. Eles devem enxergar a gestão de projetos como um facilitador e direcionador para o atendimento de suas demandas (BOUER; CARVALHO, 2005).

$O$ estudo realizado por Albertin, entre dez fatores críticos para o sucesso de projetos, destacou três principais: apoio da alta gerência; qualidade das tarefas técnicas e acompanhamento e controle (ALBERTIN, 2001).

Barbalho et al (2009) realizou em seu artigo um estudo sobre a resistência a implantação de um escritório de projetos em uma indústria médica de médio porte. Barbalho identificou em seu estudo de caso vários obstáculos: 
(1) tensão política - uma vez que o PMO poderia veicular informações sobre a situação das tarefas em um determinado período, poderia expor os desenvolvedores quanto a fragilidades de seu trabalho técnico; (2) tensão de flexibilização e padronização de atividades de planejamento e controle do projeto - a realização dessas atividades implicava em tempo que, segundo os desenvolvedores, desviava seu foco em relação às atividades de projeto propriamente ditas. A terceira tensão foi o "controle sobre a máquina do projeto", a qual surgia de duas formas: (3) uma vez que atividades como a fabricação de peças para protótipos, a coordenação dos departamentos de controle de qualidade e de manufatura / logística para o controle da rastreabilidade dos PMPs do produto, a aquisição de componentes e equipamentos, muitos dos quais importados, não tinham responsáveis bem definidos; e (4) o PMO era visto pelos desenvolvedores como o pessoal que apenas "cobra" e não "gera resultados" que fizessem o projeto avançar. (BARBALHO et al, 2009, v.16, n. 3, p. 442)

Ainda neste artigo de Barbalho et al (2009), a forma encontrada de reduzir a tensão e a resistência ao PMO pelos desenvolvedores foi atribuir ao escritório de projetos outras atividades, relacionadas não diretamente ao gerenciamento de projetos mas ao processo produtivo. Desta forma o PMO passou a desempenhar tarefas antes realizadas pelos desenvolvedores, desonerando-os de atividades que eles não consideravam importantes para o seu processo.

\subsection{Mudança Organizacional}

A mudança organizacional é, geralmente, um processo complexo, definido como a alteração de certo estado de coisas internas da organização, tendo em vista uma nova forma de comportamento coletivo, em função de um fator interno ou externo à organização (CARRIERI; LIMA; PIMENTEL, 2007). Com a crescente modificação dos mercados, aumento da exigência dos clientes e velocidade das inovações tecnológicas, a mudança passa a ser um estado praticamente permanente para as organizações (BRESSAN, 2004; DOMINGUES; BUENO, 2005). Bressan (2004), citando Weick e Quinn, salienta que a mudança é um processo constante e o ideal seria denominá-lo de "mudando" ao invés de mudança.

O tema mudança organizacional está intrinsecamente ligado à questão da resistência, visto que representa, em grande parte dos casos, alterações no status quo. Assim, esforços para mudança organizacional freqüentemente se deparam com alguma forma de resistência humana (JACOBSEN; RODRIGUES, 2002). 
Toda mudança gera resistência e, em geral, os indivíduos sentem medo do que é novo, do desconhecido. Principalmente quando a percepção da mudança vem acompanhada de um sentimento de ameaça para as situações onde a pessoa sente segurança. (DOMINGUES; BUENO, 2005).

As organizações preparadas para mudanças devem possuir um corpo funcional flexível e capaz de enfrentar desafios. Citando Lewin, a quem a expressão "resistência a mudança" é atribuída, Carrieri et al (2007) explica que, considerando que a organização seja formada por um conjunto de forças opostas que mantém um sistema em equilíbrio, a mudança surge quando uma das forças supera a outra. Este deslocamento gera resistência nos indivíduos que se sentem ameaçados em sua autoridade e privilégios.

Estudos apontados por Bressan (2004, p. 7) identificam os líderes como grandes responsáveis por facilitar a introdução das mudanças na organização:

Mudanças organizacionais significativas podem necessitar de grandes
crises e esforços para mobilizar toda a empresa quanto à sua necessidade
e devem encontrar no líder a figura fundamental na condução do processo e
mobilização dos indivíduos, da maneira mais transparente e com a melhor
comunicação possível (BRESAN, 2004, p. 7).

Domingues e Bueno (2005, p. 7) citam o estudo de Wagner III e Hollenbeck que conclui: "Não existe maneira universal e infalível de superar os fatores de resistência identificados numa análise do campo de força. (...) existem seis que são adotadas com mais freqüência". Estas seis são: a) educação e comunicação; b) participação e envolvimento; c) facilitação e apoio; d) barganha e negociação; e) persuasão oculta; f) coerção explícita e implícita.

Domingues e Bueno (2005, p. 8) descrevem as oito etapas, definidas por Kotter, que devem ser utilizadas e seguidas em sua seqüencia para garantir uma mudança bem sucedida:

Estabelecer um senso de urgência. É [...] um elemento fundamental. [...] Quando se tem um alto nível de complacência [...] o nível de interesse das pessoas é baixo para se trabalhar as questões relativas à mudança [...].

Criar uma coalizão administrativa. [...] Uma coalizão forte envolvendo pessoas de confiança, e que apresentem objetivos comuns, são fundamentais para a composição de uma equipe que não irá medir esforços para atuar frente à demanda de mudança [...].

Desenvolver uma visão estratégica. [...] Um processo de mudança exige que a direção oriente onde se quer chegar (visão). Este procedimento tende a evitar gastos financeiros e energia desnecessária [...].

Comunicar a visão da mudança. [...] A comunicação da visão da mudança, disseminando este conhecimento para todos os colaboradores na 
empresa, certamente, proporcionará um envolvimento maior e facilmente serão identificados os focos de resistência à mudança [...].

Investir de empowerment os funcionários para ações abrangentes. [...] É pouco provável que profissionais que não se desenvolveram cognitivamente e emocionalmente venham a ter ações abrangentes e de sustentação ao processo de mudança.

Realizar conquistas de curto-prazo. [...] Ignorar que conquistas a curtoprazo tenham que ser realizadas e consolidadas é muito perigoso para um processo de mudança [...].

Consolidar os ganhos de produção de mais mudanças. Este processo visa evitar que haja o surgimento da complacência. [...] À medida que se conquistem ganhos é importante entender que as mudanças são interdependentes e que novas mudanças devem ser imediatamente colocadas em fase de processo.

Estabelecer novos métodos na cultura. [...] Durante o processo da mudança a organização passou a assimilar uma nova cultura, assim sendo, percebê-la e sustentá-la é fundamental para que se consolide a cultura da mudança.

A literatura parece apontar a existência de uma resistência natural dos indivíduos às mudanças, porém em graus variados. Em suma, não é possível elaborar receituários de como lidar com a reação dos empregados às mudanças. $O$ que de fato interessa é alertar os gestores sobre a necessidade de conhecer os indivíduos e a cultura da organização, a fim de planejar as mudanças e saber lidar com as mais diferentes reações apresentadas (BRESSAN, 2004). 


\section{MÉTODOS E TÉCNICAS DE PESQUISA}

\subsection{Tipo e descrição geral da pesquisa}

Considerando a classificação de Triviños (apud ZANELLA, p. 27, 2006), o tipo de pesquisa, com relação à sua finalidade, é descritiva, pois a intenção é conhecer a realidade estudada, suas características e seus problemas.

Considerando a taxonomia de Patton (apud ZANELLA, p. 28, 2006) o presente estudo trata de uma pesquisa científica aplicada, pois tem como finalidade gerar soluções aos problemas humanos e entender como lidar com um problema.

A taxonomia de Mattar classifica as pesquisas quanto: a natureza das variáveis - qualitativas e quantitativas; relacionamento entre as varáveis - descritiva e causal; aos objetivos e o grau em que o problema está cristalizado - exploratória e conclusiva; à forma utilizada para a coleta dos dados - comunicação ou observação; ao objetivo da pesquisa - levantamentos amostrais, estudos de campo e estudos de caso; à dimensão da pesquisa no tempo - ocasionais e evolutivas; ao ambiente - de campo, de laboratório e por simulação (MATTAR apud ZANELLA, p. 30-34, 2006).

Considerando a taxonomia de Mattar o trabalho apresentado possui as seguintes classificações:

- Natureza das variáveis: quantitativa, pois a intenção é medir e quantificar os resultados da investigação, elaborando-os em dados estatísticos;

- Relacionamento entre as variáveis: causal, pois procura identificar os fatores que determinam ou contribuem para a ocorrência dos fenômenos em estudo;

- Objetivo e grau em que o problema está cristalizado: conclusiva, pois busca respostas para as questões da pesquisa;

- Forma de coleta de dados primários: comunicação, pois a coleta de informações será diretamente com o respondente; 
- Objetivo da pesquisa: estudo de caso, com característica de grande profundidade e pequena amplitude, pois será conhecida a realidade de um grupo de pessoas;

- Dimensão no tempo: ocasional, mostrando um resultado instantâneo do fenômeno estudado;

- Ambiente: pesquisa de campo, já que será aplicada em um ambiente real.

A pesquisa será realizada por comunicação, com a utilização de questionário aplicado diretamente aos respondentes, utilizando o método quantitativo. Esse método preocupa-se com a medição objetiva e quantificação dos resultados, com o objetivo de generalizar os dados de uma população, estudando somente uma pequena parcela dela. A pesquisa quantitativa é apropriada para medir tanto opiniões, atitudes e preferências, como comportamentos (ZANELLA, 2006). Os questionários serão distribuídos utilizando-se o e-mail corporativo ou impresso, dentro da amostra escolhida.

A pesquisa caracteriza-se como um levantamento, do ponto de vista dos procedimentos técnicos, por envolver a interrogação direta das pessoas cujo comportamento deseja-se conhecer (GIL apud SILVA; MENEZES, p. 21, 2001).

\subsection{Caracterização da organização, setor ou área do objeto de estudo}

O Banco Comercial estudado é uma pessoa jurídica de direito privado, sociedade anônima aberta, de economia mista, organizada sob a forma de banco múltiplo. Pela característica de uma Sociedade Anônima, tem as suas ações negociadas em Bolsa de Valores. A União Federal possui o controle da empresa, pois é detentora de 59,2\% de suas ações, posição de setembro de 2010. Em junho de 2010, a empresa possuía um total de 116.370 colaboradores, sendo 106.241 funcionários e 10.129 estagiários (PORTAL do Banco na Internet).

Com o propósito de envolver todos os executivos na definição de estratégias e na aprovação de propostas para os diferentes negócios do Banco, as decisões, em qualquer nível da empresa, são tomadas de forma colegiada. Ressalvadas as 
situações em que uma estrutura organizacional mínima não o permita, a administração utiliza comitês, subcomitês e comissões de nível estratégico, que garantem agilidade, qualidade e segurança à tomada de decisão (PORTAL do Banco na Internet).

A estrutura organizacional do Banco é composta por 23 Unidades Estratégicas, entre as quais 9 vice-presidências. Subordinadas ao Presidente e às Vice-Presidências são 27 diretorias (PORTAL do Banco na Internet).

A Diretoria de Tecnologia, DITEC, é composta por duas Unidades Estratégicas voltadas para Estruturação e Construção de Soluções de TI, UECS1 e UECS2; e uma Unidade Estratégica voltada para a Operação de Soluções de TI, UOS. Ligada diretamente ao Diretor temos a área de Governança de $\mathrm{TI}$ e uma Divisão para assuntos administrativos (PORTAL do Banco na Internet).

O presente estudo será realizado exclusivamente na Gerência de Portfólio e Projetos, que faz parte da UECS2 da DITEC, e seus resultados estarão limitados a abrangência da mesma.

A UECS2 é composta por oito Gerências Executivas, sendo uma gerência de relacionamento com o cliente, uma de gestão de portfólios e projetos, quatro de construção de aplicações (softwares), uma de construção de componentes de infraestrutura e uma de integração.

A Gerência de Portfólio e Projetos, GPP, possui um Gerente Executivo, 5 Gerentes de Divisão, 12 Gerentes de Equipe. Uma divisão é responsável pela gestão do portfólio de projetos, apoiando os subcomitês com informações e estudos para a priorização. Nessa divisão também se encontra a equipe responsável por manter as ferramentas que apóiam a gestão dos projetos e os manuais, guias e metodologias que orientam os gerentes na gestão de suas carteiras de projetos. As outras quatro divisões se dedicam exclusivamente às atividades relacionadas à gestão de projetos e programas.

O número de colaboradores das demais Gerências da UECS2 é, em média, de 140 pessoas, e possuem os mesmos cargos da GPP, variando a quantidade conforme a especificidade de cada uma. 


\subsubsection{Visão Geral da Gestão por Projetos na TI do Banco Estudado}

A introdução da gestão por projetos na área de tecnologia do Banco iniciouse em 2003. Em um primeiro modelo, manteve-se a estrutura funcional e o próprio analista de sistemas, responsável pela construção da solução e entrega do produto, passou a acumular a função de líder de projeto. Desta forma aumentou a sua quantidade de tarefas, uma vez que assumiu outras responsabilidades, como elaboração de cronogramas, relatórios de acompanhamento e desempenho, reuniões com patrocinadores e clientes. Além disso, não existia segregação das atividades da engenharia de software, ficando uma única equipe responsável por todas as fases do ciclo de desenvolvimento: levantamento dos requisitos, análise, projeto, construção, testes e implantação (Intranet Corporativa, Governança de TI, 2011).

Em um primeiro movimento, foram criadas equipes especializadas dentro de cada gerência de construção de soluções, iniciando por equipe de levantamento de requisitos que ficariam com esta atribuição no projeto, retirando-a do analista de sistemas. O segundo e terceiros movimentos foram a criação de equipes formadas exclusivamente por líderes de projeto e equipes para teste e garantia de qualidade (Intranet Corporativa, Governança de TI, 2011).

Em um último movimento, as equipes de requisitos, projetos e testes foram retiradas das gerências de construção e formaram estruturas independentes. Criouse uma estrutura matricial, com gerências distintas e especializadas, uma em gerenciamento de projetos, outra em levantamento de requisitos, diversas em construção de soluções de software, e uma de testes e garantia da qualidade (Intranet Corporativa, Governança de TI, 2011).

Atualmente, a estrutura organizacional da Diretoria de Tecnologia utilizada para a condução dos projetos é a matricial fraca, uma vez que se assemelha com a estrutura funcional, e os gerentes funcionais possuem um maior poder em comparação aos gerentes de projeto. A Gerência de Projetos abriga os líderes de projeto que estruturam as equipes com os recursos negociados nas outras gerências, que se dedicam de forma parcial ou integral ao projeto. Os líderes não possuem nenhum poder administrativo sobre a equipe, cujos membros 
permanecem, durante a participação no projeto, subordinados hierarquicamente aos seus gerentes funcionais.

\subsection{População e amostra}

O presente estudo foi realizado exclusivamente na Gerência de Portfólio e Projetos, que faz parte da UECS2 da DITEC, e seus resultados estão limitados a abrangência dela. As fontes primárias da pesquisa são os colaboradores lotados na GPP, até o nível de Gerente de Equipe, que atuam diretamente na liderança de projetos, o que delimita uma população de 85 pessoas.

O procedimento para estabelecimento da amostra foi baseado nas técnicas de amostra aleatória. Citando Kazmier (apud Zanchin, 2002, p.56) define que:

[...] amostra aleatória é extraída por um procedimento tal que cada elemento da população tenha uma probabilidade conhecida de ser escolhido e que não possua nenhuma fonte conhecida de erro sistemático (ZANCHIN, R., 2002, p. 56).

Os questionários foram enviados para toda a população selecionada, 85 pessoas, e a amostra foi determinada pelo número de pessoas que receberam os questionários e os retornaram preenchidos. A técnica utilizada foi a Amostragem Aleatória Simples, onde cada elemento da população tem igual probabilidade de integrar a amostra (ZANCHIN, R., 2002).

\subsection{Instrumento de pesquisa}

O instrumento de pesquisa utilizado é um questionário objetivo baseado na escala de Likert (ALEXANDRE et al, 2003) com perguntas de respostas fechadas que enquadram-se em uma escala de intervalo, (1) concordo totalmente (2) concordo em parte (3) neutro (4) discordo em parte (5) discordo totalmente (ZANELLA, 2006).

A decisão pela utilização da escala de Likert para esta pesquisa amparouse, principalmente, no amplo conhecimento e aceitação deste tipo de questionário pelas pessoas pertencentes à população pesquisada. Além disso, esta escala possui vantagens em relação às outras que também foram consideradas na sua 
escolha, conforme MATTAR (2001): simplicidade de construção e a amplitude de respostas permitidas.

Considerando as dificuldades para o sucesso no gerenciamento de projetos identificados no referencial teórico, foi realizada uma qualificação dos mesmos agrupando-os por afinidade. Esta categorização visa facilitar a análise dos resultados e baseou a construção do questionário de pesquisa. A organização proposta é a seguinte:

\begin{tabular}{|c|c|}
\hline $\begin{array}{r}\text { Problemas organizacionais e da } \\
\text { alta gerência }\end{array}$ & $\begin{array}{l}\text { - Falta de apoio da alta gerência } \\
\text { - Estrutura organizacional inadequada para } \\
\text { trabalhar com projetos } \\
\text { - } \text { Dimensionamento errado do grupo de projeto } \\
\text { - Falta de comprometimento das pessoas } \\
\text { envolvidas }\end{array}$ \\
\hline $\begin{array}{r}\text { Problemas relacionados aos } \\
\text { líderes de projetos }\end{array}$ & $\begin{array}{l}\text { - Falta de agilidade e pró-atividade } \\
\text { - Falta de planejamento adequado } \\
\text { - Capacitação dos gerentes de projeto insuficiente } \\
\text { - Acompanhamento e controle ineficientes }\end{array}$ \\
\hline $\begin{array}{r}\text { Problemas relacionados aos } \\
\text { desenvolvedores }\end{array}$ & $\begin{array}{l}\text { - Falta de agilidade e pró-atividade } \\
\text { - Falta de experiência dos integrantes do projeto } \\
\text { - Qualidade das tarefas técnicas }\end{array}$ \\
\hline $\begin{array}{r}\text { Problemas relacionados a } \\
\text { terceiros }\end{array}$ & $\begin{array}{l}\text { - Grande dependência de terceiros } \\
\text { - Falta de clareza na definição de contrato com } \\
\text { - fornecedores } \\
\text { - Problemas de logística }\end{array}$ \\
\hline
\end{tabular}

Quadro 5 - Agrupamento dos problemas por afinidade

Fonte: Criado pelo autor

O questionário foi organizado com quatorze (14) perguntas. Cada um dos problemas pertencentes aos quatro grupos que aparecem no Quadro 5 deu origem a uma pergunta, perfazendo as questões. A ordem das perguntas segue a descrita na categorização. Isto porque foram seguidas as recomendações de Rea e Parker (apud ZANELLA, 2006, p. 110) sobre a estruturação do questionário, ou seja, as perguntas introdutórias devem ser relacionadas ao assunto do preâmbulo e estimular o preenchimento do instrumento, sendo simples e descomplicadas; as perguntas delicadas devem ficar mais ao final do questionário; perguntas afins devem ser colocadas juntas, na seqüencia; realizar verificações da confiabilidade da resposta, repetindo a mesma pergunta, mas formulada de maneira diferente, em outro lugar do questionário (ZANELLA, 2006). 
O respondente deve identificar o seu cargo e o tempo de trabalho na DITEC. Estas informações serão utilizadas na análise dos resultados.

\subsection{Procedimentos de coleta e de análise de dados}

O processo de análise de dados é definido por Kerlinger (1980, p.353) como "a categorização, ordenação, manipulação e sumarização de dados". Tem por objetivo reduzir grandes quantidades de dados brutos a uma forma interpretável e mensurável (ZANELLA, 2006).

A técnica de análise de dados utilizada nesta pesquisa é a análise estatística. Este tipo de análise mostra a relação entre as varáveis por meio de gráficos, classificados por categorias e medidos por cálculos estatísticos (ZANELLA, 2006).

Para a análise dos dados é utilizado o software Microsoft Office Excel 2003. Como apoio, o questionário foi elaborado no aplicativo GoogleDocs e pode ser visualizado no Anexo 3. O aplicativo permite que o questionário seja enviado para os pesquisados por e-mail e consolida as respostas automaticamente em uma planilha que pode ser vista no Anexo 2, gerando alguns gráficos estatísticos, conforme Anexo 4. Outras análises, além das fornecidas pelo aplicativo, foram necessárias uma vez que o instrumento não realiza cruzamento por grupamentos de variáveis, como por exemplo, resultados separados para gerentes e analistas ou por tempo de DITEC, que são outras variáveis da pesquisa. 


\section{RESULTADOS E DISCUSSÃO}

Os resultados são apresentados em termos percentuais considerando toda a amostra, o cargo dos respondentes quanto à diferenciação entre Gerentes e Assessores e o tempo de trabalho na Diretoria de Tecnologia. A intenção de utilização da variável tempo de trabalho na DITEC é identificar se ela é relevante a ponto de influenciar as respostas. A variável de função, Gerente e Assessor, será utilizada para fazer um comparativo entre a percepção dos funcionários e a de seus gerentes.

Para expor os resultados foram utilizados quadros organizados nos quatro agrupamentos de problemas propostos para a pesquisa: organizacionais e da alta gerência, relacionados aos líderes de projeto, relacionados aos desenvolvedores e relacionados a terceiros. No Anexo 4 estão alguns gráficos que apoiaram a análise.

Com relação ao cargo, 29 pessoas (83\%) se identificaram como assessores e seis (17\%) como gerentes. Nenhum colaborador possui menos de um ano de DITEC. Quinze funcionários (43\%) estão na faixa de 1 a 5 anos; nove (26\%) possuem de 5 a 10 anos e onze (31\%) têm mais de 10 anos.

\begin{tabular}{|c|c|c|c|c|c|c|c|}
\hline Questões & Escala & Amostra & Gerente & Assessor & $\begin{array}{l}1 \text { a } 5 \\
\text { anos }\end{array}$ & $\begin{array}{l}5 \text { a } 10 \\
\text { anos }\end{array}$ & $\begin{array}{l}\text { Mais } 10 \\
\text { anos }\end{array}$ \\
\hline \multirow{5}{*}{$\begin{array}{l}\text { O apoio da alta } \\
\text { gerência foi } \\
\text { determinante nos } \\
\text { projetos em que } \\
\text { participei. }\end{array}$} & 1 concordo totalmente & $34 \%$ & $17 \%$ & $38 \%$ & $40 \%$ & $33 \%$ & $27 \%$ \\
\hline & 2 concordo em parte & $49 \%$ & $67 \%$ & $45 \%$ & $33 \%$ & $56 \%$ & $64 \%$ \\
\hline & 3 neutro & $9 \%$ & $0 \%$ & $10 \%$ & $20 \%$ & $0 \%$ & $0 \%$ \\
\hline & 4 discordo em parte & $6 \%$ & $17 \%$ & $3 \%$ & $0 \%$ & $11 \%$ & $9 \%$ \\
\hline & 5 discordo totalmente & $3 \%$ & $0 \%$ & $3 \%$ & $7 \%$ & $0 \%$ & $0 \%$ \\
\hline \multirow{6}{*}{$\begin{array}{l}\text { A estrutura } \\
\text { organizacional da } \\
\text { DITEC colabora para o } \\
\text { sucesso dos projetos. }\end{array}$} & & & & & & & \\
\hline & 1 concordo totalmente & $3 \%$ & $0 \%$ & $3 \%$ & $0 \%$ & $0 \%$ & $9 \%$ \\
\hline & 2 concordo em parte & $14 \%$ & $17 \%$ & $14 \%$ & $13 \%$ & $0 \%$ & $27 \%$ \\
\hline & 3 neutro & $20 \%$ & $17 \%$ & $21 \%$ & $33 \%$ & $11 \%$ & $9 \%$ \\
\hline & 4 discordo em parte & $37 \%$ & $33 \%$ & $38 \%$ & $40 \%$ & $44 \%$ & $27 \%$ \\
\hline & 5 discordo totalmente & $26 \%$ & $33 \%$ & $24 \%$ & $13 \%$ & $44 \%$ & $27 \%$ \\
\hline \multirow{5}{*}{$\begin{array}{l}\text { O dimensionamento } \\
\text { das equipes dos } \\
\text { projetos é adequado } \\
\text { para a sua realização. }\end{array}$} & 1 concordo totalmente & $6 \%$ & $0 \%$ & $7 \%$ & $0 \%$ & $0 \%$ & $18 \%$ \\
\hline & 2 concordo em parte & $14 \%$ & $33 \%$ & $10 \%$ & $20 \%$ & $0 \%$ & $18 \%$ \\
\hline & 3 neutro & $20 \%$ & $0 \%$ & $24 \%$ & $33 \%$ & $11 \%$ & $9 \%$ \\
\hline & 4 discordo em parte & $40 \%$ & $50 \%$ & $38 \%$ & $33 \%$ & $44 \%$ & $45 \%$ \\
\hline & 5 discordo totalmente & $20 \%$ & $17 \%$ & $21 \%$ & $13 \%$ & $44 \%$ & $9 \%$ \\
\hline \multirow{5}{*}{$\begin{array}{l}\text { As pessoas envolvidas } \\
\text { com o projeto estão } \\
\text { comprometidas com as } \\
\text { suas atividades. }\end{array}$} & 1 concordo totalmente & $14 \%$ & $33 \%$ & $10 \%$ & $13 \%$ & $22 \%$ & $9 \%$ \\
\hline & 2 concordo em parte & $43 \%$ & $17 \%$ & $48 \%$ & $53 \%$ & $22 \%$ & $45 \%$ \\
\hline & 3 neutro & $14 \%$ & $0 \%$ & $17 \%$ & $13 \%$ & $33 \%$ & $0 \%$ \\
\hline & 4 discordo em parte & $26 \%$ & $50 \%$ & $21 \%$ & $13 \%$ & $22 \%$ & $45 \%$ \\
\hline & 5 discordo totalmente & $3 \%$ & $0 \%$ & $3 \%$ & $7 \%$ & $0 \%$ & $0 \%$ \\
\hline
\end{tabular}

Quadro 6 - Problemas organizacionais e da alta gerência

Fonte: Criado pelo autor 
O apoio da alta gerência tem sido determinante no sucesso dos projetos para $83 \%$ dos pesquisados. Este resultado demonstra que o apoio tem acontecido, é importante para os projetos e deve ser mantido.

Para $63 \%$ das pessoas a estrutura organizacional é inadequada para a condução dos projetos. Este percentual aumenta para $88 \%$ considerando as pessoas com de 5 a 10 anos de DITEC.

O dimensionamento das equipes de projeto parece inadequado para $60 \%$ dos entrevistados e também aumenta para $88 \%$ quando o tempo de DITEC está entre 5 a 10 anos.

Embora o dimensionamento das equipes pareça inadequado, as pessoas envolvidas com o projeto demonstram comprometimento, conforme relatado por $57 \%$ dos entrevistados.

Analisando a constatação de estrutura organizacional e dimensionamento das equipes inadequadas, a falta de poder do líder sobre a equipe pode justificar estes números. Com a utilização de uma organização matricial fraca, a dificuldade para a formação e manutenção da equipe do projeto pelo líder é muito grande. Ele precisa negociar freqüentemente com os gerentes funcionais de outras gerências que cederam os funcionários para o projeto, porém não está investido deste poder. Precisa recorrer ao seu próprio gerente para que interceda nos projetos e negocie com os gerentes das outras áreas a cessão e permanência dos recursos no projeto.

\begin{tabular}{|c|c|c|c|c|c|c|c|}
\hline Questões & Escala & $\begin{array}{l}\text { Amos } \\
\text { tra }\end{array}$ & Gerente & Assessor & $\begin{array}{l}1 \text { a } 5 \\
\text { anos }\end{array}$ & $\begin{array}{l}5 \text { a } 10 \\
\text { anos }\end{array}$ & $\begin{array}{l}\text { Mais } 10 \\
\text { anos }\end{array}$ \\
\hline \multirow{5}{*}{$\begin{array}{l}\text { O líder de projeto age } \\
\text { com rapidez e pro - } \\
\text { atividade na solução dos } \\
\text { problemas. }\end{array}$} & 1 concordo totalmente & $20 \%$ & $0 \%$ & $24 \%$ & $27 \%$ & $33 \%$ & $0 \%$ \\
\hline & 2 concordo em parte & $51 \%$ & $33 \%$ & $55 \%$ & $53 \%$ & $67 \%$ & $36 \%$ \\
\hline & 3 neutro & $14 \%$ & $33 \%$ & $10 \%$ & $13 \%$ & $0 \%$ & $27 \%$ \\
\hline & 4 discordo em parte & $14 \%$ & $33 \%$ & $10 \%$ & $7 \%$ & $0 \%$ & $36 \%$ \\
\hline & 5 discordo totalmente & $0 \%$ & $0 \%$ & $0 \%$ & $0 \%$ & $0 \%$ & $0 \%$ \\
\hline \multirow{5}{*}{$\begin{array}{l}\text { Os planejamentos tem se } \\
\text { mostrado adequados, } \\
\text { sofrendo mínimas } \\
\text { alterações durante o ciclo } \\
\text { de vida dos projetos. }\end{array}$} & 1 concordo totalmente & $3 \%$ & $17 \%$ & $0 \%$ & $0 \%$ & $0 \%$ & $9 \%$ \\
\hline & 2 concordo em parte & $6 \%$ & $0 \%$ & $7 \%$ & $7 \%$ & $0 \%$ & $9 \%$ \\
\hline & 3 neutro & $20 \%$ & $0 \%$ & $24 \%$ & $20 \%$ & $33 \%$ & $9 \%$ \\
\hline & 4 discordo em parte & $34 \%$ & $33 \%$ & $34 \%$ & $40 \%$ & $22 \%$ & $36 \%$ \\
\hline & 5 discordo totalmente & $37 \%$ & $50 \%$ & $34 \%$ & $33 \%$ & $44 \%$ & $36 \%$ \\
\hline \multirow{5}{*}{$\begin{array}{l}\text { Os líderes de projeto } \\
\text { possuem a capacitação } \\
\text { necessária para } \\
\text { exercerem as suas } \\
\text { atribuições. }\end{array}$} & 1 concordo totalmente & $6 \%$ & $0 \%$ & $7 \%$ & $7 \%$ & $0 \%$ & $9 \%$ \\
\hline & 2 concordo em parte & $43 \%$ & $33 \%$ & $45 \%$ & $60 \%$ & $44 \%$ & $18 \%$ \\
\hline & 3 neutro & $20 \%$ & $50 \%$ & $14 \%$ & $13 \%$ & $22 \%$ & $27 \%$ \\
\hline & 4 discordo em parte & $23 \%$ & $17 \%$ & $24 \%$ & $20 \%$ & $11 \%$ & $36 \%$ \\
\hline & 5 discordo totalmente & $9 \%$ & $0 \%$ & $10 \%$ & $0 \%$ & $22 \%$ & $9 \%$ \\
\hline \multirow{5}{*}{$\begin{array}{l}\text { Os projetos são } \\
\text { acompanhados } \\
\text { eficientemente, com } \\
\text { relatórios de controle e } \\
\text { gerenciamento de riscos. }\end{array}$} & 1 concordo totalmente & $3 \%$ & $0 \%$ & $3 \%$ & $7 \%$ & $0 \%$ & $0 \%$ \\
\hline & 2 concordo em parte & $46 \%$ & $33 \%$ & $48 \%$ & $53 \%$ & $33 \%$ & $45 \%$ \\
\hline & 3 neutro & $17 \%$ & $0 \%$ & $21 \%$ & $13 \%$ & $33 \%$ & $9 \%$ \\
\hline & 4 discordo em parte & $29 \%$ & $50 \%$ & $24 \%$ & $27 \%$ & $22 \%$ & $36 \%$ \\
\hline & 5 discordo totalmente & $6 \%$ & $17 \%$ & $3 \%$ & $0 \%$ & $11 \%$ & $9 \%$ \\
\hline
\end{tabular}

Quadro 7 - Problemas relacionados aos líderes de projeto

Fonte: Criado pelo autor 
A maioria dos colaboradores, $71 \%$, considera que os líderes de projeto têm uma boa atuação na solução dos problemas. Observa-se uma diferença considerável entre a percepção dos Gerentes e Assessores sobre este aspecto. Dos primeiros, apenas $33 \%$ concordam em parte com a afirmativa; dos segundos, $79 \%$. Esta diferença pode indicar a necessidade dos Gerentes esclarecerem aos seus Assessores o que é esperado sobre o seu desempenho. Principalmente porque esta diferença não é observada para as pessoas com mais de dez anos de DITEC (36\%), indicando que para os colaboradores mais inexperientes parece não estar claro o que se espera deles na solução dos problemas dos projetos.

Quanto ao planejamento dos projetos, a opinião de $71 \%$ da amostra é que ele é inadequado e sofre muitas alterações durante o ciclo de vida do projeto. Esta constatação indica planejamentos inadequados. As razões de erros no planejamento são muitas: imposição de atividades e datas à equipe, sem negociação prévia; utilizar conjunto de regras e procedimentos que deram certo em outros projetos mas que não possuem as mesmas características do atual; tendência natural das pessoas ao atraso; não dedicar o tempo necessário para conhecer os requisitos a ponto de melhorar as estimativas; cronogramas feitos considerando uma visão otimista (BERKUN, 2008). Um processo de iniciação deficiente pode levar a decisões equivocadas no planejamento. Além disso, a falta de garantia da manutenção da equipe de projeto provocada pela estrutura proposta, matricial fraca, também é um fator que provoca freqüentes replanejamentos.

A capacitação dos líderes de projeto é considerada adequada por $49 \%$ da amostra. Considerando apenas os gerentes, esta concordância é de apenas $37 \%$ e para aqueles com mais de dez anos de DITEC, 27\%. A maioria é obtida no grupo de assessores, 57\%, principalmente naqueles entre um e cinco anos de DITEC, 67\%. Assim como na percepção da habilidade dos líderes para solução de problemas, observamos aqui a mesma divergência entre assessores até dez anos de DITEC e os Gerentes e aqueles com mais de dez anos. A necessidade de capacitação dos profissionais é constante para que estejam sempre acompanhando as inovações do mercado, notadamente na área de tecnologia que evolui muito rapidamente. A pesquisa mostra que a percepção desta necessidade é mais clara para os funcionários mais experientes, que conseguem identificar nos líderes de projeto pontos de melhoria que a capacitação poderia suprir. 
O acompanhamento dos projetos mostra-se adequado por $49 \%$ dos pesquisados e inadequado para $35 \%$ deles. Considerando só os Gerentes, a situação é inversa. A aprovação neste grupo é de apenas 33\%, e $67 \%$ acha que os acompanhamentos são inadequados.

\begin{tabular}{|c|c|c|c|c|c|c|c|}
\hline Questões & Escala & Amostra & Gerente & Assessor & $\begin{array}{l}1 \text { a } 5 \\
\text { anos }\end{array}$ & $\begin{array}{l}5 \text { a } 10 \\
\text { anos }\end{array}$ & $\begin{array}{l}\text { Mais } 10 \\
\text { anos }\end{array}$ \\
\hline \multirow{5}{*}{$\begin{array}{l}\text { Os Responsáveis } \\
\text { Técnicos demonstram } \\
\text { pró-atividade e } \\
\text { agilidade na solução } \\
\text { dos problemas. }\end{array}$} & 1 concordo totalmente & $6 \%$ & $0 \%$ & $7 \%$ & $0 \%$ & $11 \%$ & $9 \%$ \\
\hline & 2 concordo em parte & $37 \%$ & $33 \%$ & $38 \%$ & $53 \%$ & $22 \%$ & $27 \%$ \\
\hline & 3 neutro & $31 \%$ & $17 \%$ & $34 \%$ & $20 \%$ & $44 \%$ & $36 \%$ \\
\hline & 4 discordo em parte & $20 \%$ & $33 \%$ & $17 \%$ & $20 \%$ & $22 \%$ & $18 \%$ \\
\hline & 5 discordo totalmente & $6 \%$ & $17 \%$ & $3 \%$ & $7 \%$ & $0 \%$ & $9 \%$ \\
\hline \multirow{5}{*}{$\begin{array}{l}\text { O nível de } \\
\text { conhecimento e } \\
\text { experiência dos RT } \\
\text { são adequados para o } \\
\text { desenvolvimento de } \\
\text { suas atividades. }\end{array}$} & 1 concordo totalmente & $9 \%$ & $17 \%$ & $7 \%$ & $13 \%$ & $0 \%$ & $9 \%$ \\
\hline & 2 concordo em parte & $57 \%$ & $67 \%$ & $55 \%$ & $47 \%$ & $67 \%$ & $64 \%$ \\
\hline & 3 neutro & $17 \%$ & $17 \%$ & $17 \%$ & $13 \%$ & $11 \%$ & $27 \%$ \\
\hline & 4 discordo em parte & $17 \%$ & $0 \%$ & $21 \%$ & $27 \%$ & $22 \%$ & $0 \%$ \\
\hline & 5 discordo totalmente & $0 \%$ & $0 \%$ & $0 \%$ & $0 \%$ & $0 \%$ & $0 \%$ \\
\hline \multirow{5}{*}{$\begin{array}{l}\text { As entregas dos } \\
\text { desenvolvedores } \\
\text { possuem o nível de } \\
\text { qualidade esperada. }\end{array}$} & 1 concordo totalmente & $9 \%$ & $17 \%$ & $7 \%$ & $7 \%$ & $11 \%$ & $9 \%$ \\
\hline & 2 concordo em parte & $51 \%$ & $33 \%$ & $55 \%$ & $67 \%$ & $44 \%$ & $36 \%$ \\
\hline & 3 neutro & $14 \%$ & $0 \%$ & $17 \%$ & $7 \%$ & $22 \%$ & $18 \%$ \\
\hline & 4 discordo em parte & $26 \%$ & $50 \%$ & $21 \%$ & $20 \%$ & $22 \%$ & $36 \%$ \\
\hline & 5 discordo totalmente & $0 \%$ & $0 \%$ & $0 \%$ & $0 \%$ & $0 \%$ & $0 \%$ \\
\hline
\end{tabular}

Quadro 8 - Problemas relacionados aos desenvolvedores Fonte: Criado pelo autor

A pró-atividade e agilidade na solução de problemas pelos desenvolvedores são observadas por $43 \%$ dos entrevistados. $31 \%$ deles são neutros em relação a este assunto. Dos Gerentes, 50\% discordam que esta agilidade e pró-atividade sejam demonstradas pelos Responsáveis Técnicos. Pelo número de discordâncias, $26 \%$ da amostra total, pode-se considerar que este é um problema que não influencia os projetos negativamente. Estas respostas estão coerentes com os índices apresentados à resposta sobre o comprometimento da equipe do projeto.

O conhecimento e experiência dos desenvolvedores são considerados adequados por $66 \%$ dos pesquisados. Trata-se de um ponto forte que auxilia na condução dos projetos.

A qualidade da entrega pelos desenvolvedores foi considerada adequada por $60 \%$ dos entrevistados. Evidencia-se o reconhecimento da capacidade dos profissionais na entrega de produtos com qualidade sem comprometer este item nos projetos. 


\begin{tabular}{|c|c|c|c|c|c|c|c|}
\hline Questões & Escala & Amostra & Gerente & Assessor & $\begin{array}{l}1 \text { a } 5 \\
\text { anos }\end{array}$ & $\begin{array}{l}5 \text { a } 10 \\
\text { anos }\end{array}$ & $\begin{array}{l}\text { Mais } 10 \\
\text { anos }\end{array}$ \\
\hline \multirow{5}{*}{$\begin{array}{l}\text { A dependência de } \\
\text { entidades externas tem } \\
\text { comprometido os } \\
\text { projetos em que as } \\
\text { mesmas participam. }\end{array}$} & 1 concordo totalmente & $6 \%$ & $0 \%$ & $7 \%$ & $7 \%$ & $11 \%$ & $0 \%$ \\
\hline & 2 concordo em parte & $17 \%$ & $17 \%$ & $17 \%$ & $7 \%$ & $33 \%$ & $18 \%$ \\
\hline & 3 neutro & $54 \%$ & $67 \%$ & $52 \%$ & $53 \%$ & $44 \%$ & $64 \%$ \\
\hline & 4 discordo em parte & $17 \%$ & $17 \%$ & $17 \%$ & $27 \%$ & $11 \%$ & $9 \%$ \\
\hline & 5 discordo totalmente & $6 \%$ & $0 \%$ & $7 \%$ & $7 \%$ & $0 \%$ & $9 \%$ \\
\hline \multirow{5}{*}{$\begin{array}{l}\text { O contrato com } \\
\text { fornecedores tem a } \\
\text { clareza necessária } \\
\text { para um } \\
\text { gerenciamento de } \\
\text { aquisições com } \\
\text { qualidade. }\end{array}$} & 1 concordo totalmente & $0 \%$ & $0 \%$ & $0 \%$ & $0 \%$ & $0 \%$ & $0 \%$ \\
\hline & 2 concordo em parte & $11 \%$ & $0 \%$ & $14 \%$ & $0 \%$ & $11 \%$ & $27 \%$ \\
\hline & 3 neutro & $49 \%$ & $67 \%$ & $45 \%$ & $60 \%$ & $33 \%$ & $45 \%$ \\
\hline & 4 discordo em parte & $31 \%$ & $33 \%$ & $31 \%$ & $27 \%$ & $44 \%$ & $27 \%$ \\
\hline & 5 discordo totalmente & $9 \%$ & $0 \%$ & $10 \%$ & $13 \%$ & $11 \%$ & $0 \%$ \\
\hline \multirow{5}{*}{$\begin{array}{l}\text { Projetos que envolvem } \\
\text { logísticas, tais como } \\
\text { transporte de } \\
\text { materiais, sofrem com } \\
\text { problemas de } \\
\text { execução. }\end{array}$} & 1 concordo totalmente & $6 \%$ & $17 \%$ & $3 \%$ & $7 \%$ & $0 \%$ & $9 \%$ \\
\hline & 2 concordo em parte & $37 \%$ & $33 \%$ & $38 \%$ & $27 \%$ & $56 \%$ & $36 \%$ \\
\hline & 3 neutro & $46 \%$ & $33 \%$ & $48 \%$ & $47 \%$ & $44 \%$ & $45 \%$ \\
\hline & 4 discordo em parte & $11 \%$ & $17 \%$ & $10 \%$ & $20 \%$ & $0 \%$ & $9 \%$ \\
\hline & 5 discordo totalmente & $0 \%$ & $0 \%$ & $0 \%$ & $0 \%$ & $0 \%$ & $0 \%$ \\
\hline
\end{tabular}

Quadro 9 - Problemas relacionados a terceiros

Fonte: Criado pelo autor

O comprometimento dos projetos pela dependência de entidades externas foi apontado por $23 \%$ dos colaboradores, sendo que exatamente o mesmo percentual discorda deste comprometimento. Uma grande parte, 54\%, mostrou-se neutra em relação a este tema. Esta neutralidade parece indicar que não houve participação de entidades externas nos projetos que eles participaram, significando que não teriam como opinar sobre este assunto.

Quanto aos contratos com fornecedores, apenas 11\% concordam que eles possuem a clareza necessária para um processo de aquisições com qualidade e $40 \%$ indicam que eles não possuem esta clareza. Isto indica uma necessidade de maior atenção na elaboração destes contratos. O índice de neutralidade também foi alto, 49\%. Tal fato deve-se a que poucos projetos têm, em seu escopo, a realização de contratos de aquisição. Normalmente esse contrato é produto de um projeto específico para aquisição ou é tratado como atividade operacional da área de compras.

Problemas de logística foram apontados por 43\% dos entrevistados, sendo que $49 \%$ foram neutros em sua opinião. Poucos discordaram destes problemas, apenas $11 \%$. Isto indica que a logística é um aspecto que merece atenção e precisa ser melhorada para os projetos que dependem deste tipo de atividades. Pela característica da empresa, processos de transporte e aquisições estão sujeitos à Lei 
8.666/93, Lei das Licitações, o que pode ser um fator que, embora não possa ser eliminado, justifica possíveis problemas de logística pela morosidade dos processos licitatórios em comparação a uma compra direta no mercado.

No Quadro 10 e no Gráfico 1, são apresentados os resultados agrupados por categorias. Foram construídos agrupando-se as respostas pelas categorias propostas no Quadro 5, considerando como baixa influência no sucesso dos projetos as que concordavam totalmente ou parcialmente e como alta aquelas que discordavam parcialmente ou totalmente. Cabe uma ressalva apenas para a categoria que trata das dificuldades relacionadas a terceiros. Neste caso, as respostas às afirmativas 12 e 14 têm interpretação contrária quanto à influência no sucesso dos projetos, portanto foram consideradas de maneira inversa às demais para a composição do quadro.

\begin{tabular}{|l|c|c|c|c|}
\hline $\begin{array}{c}\text { Influência no } \\
\text { sucesso dos } \\
\text { projetos }\end{array}$ & $\begin{array}{c}\text { Organizacionais e } \\
\text { da alta gerência }\end{array}$ & $\begin{array}{c}\text { Relacionados aos } \\
\text { lideres de projeto }\end{array}$ & $\begin{array}{c}\text { Relacionados aos } \\
\text { desenvolvedores }\end{array}$ & $\begin{array}{c}\text { Relacionados a } \\
\text { terceiros }\end{array}$ \\
\hline Baixa & $44 \%$ & $44 \%$ & $56 \%$ & $15 \%$ \\
\hline Neutro & $16 \%$ & $18 \%$ & $21 \%$ & $50 \%$ \\
\hline Alta & $40 \%$ & $38 \%$ & $23 \%$ & $35 \%$ \\
\hline
\end{tabular}

Quadro 10 - Dificuldades agrupadas por categorias

Fonte: Criado pelo autor

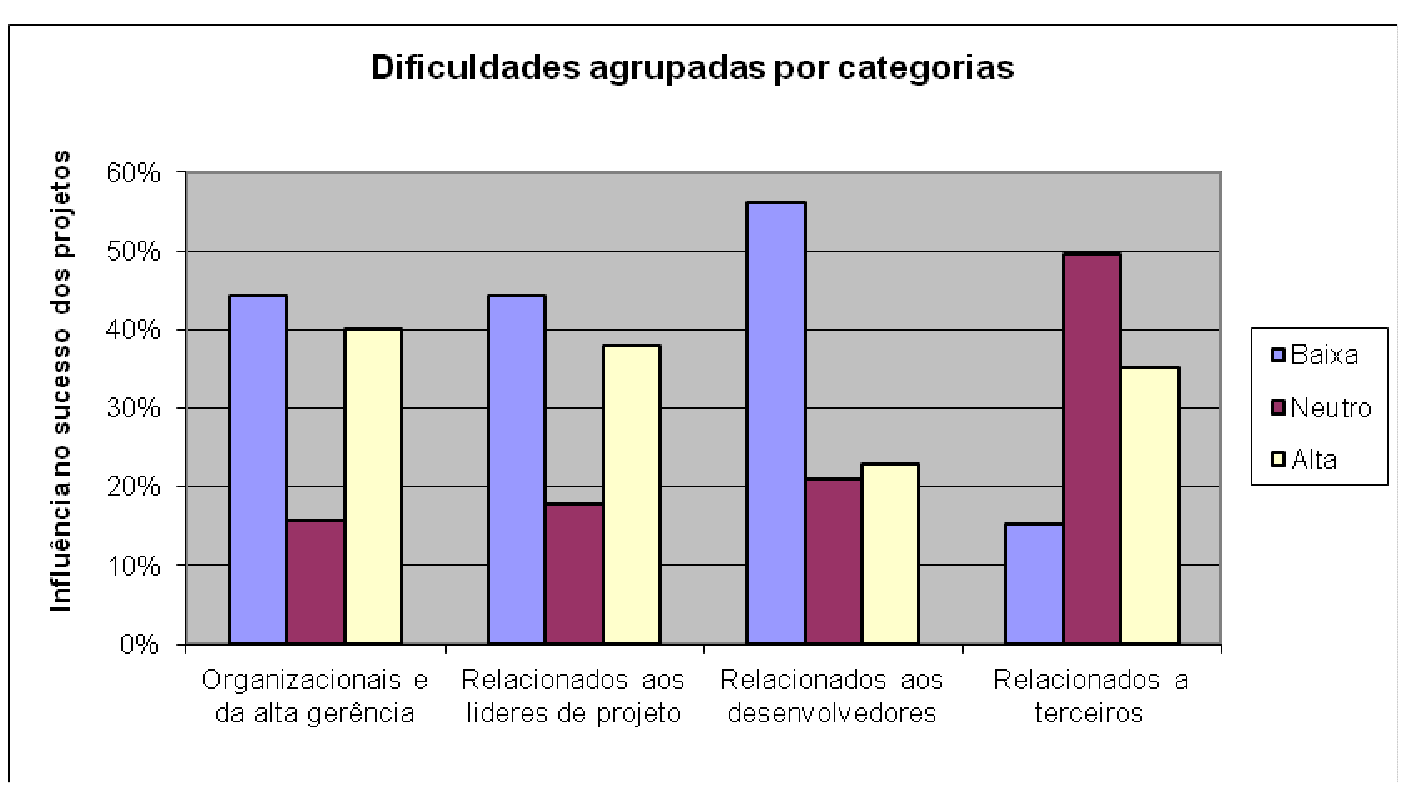

Gráfico 1 - Dificuldades agrupadas por categorias

Fonte: Criado pelo autor 
A avaliação destes resultados indica que os problemas organizacionais e da alta gerência são os que mais impactam os projetos, concentrados na estrutura organizacional, que não colabora para a gestão dos projetos, e em equipes com dimensionamento inadequado.

O baixo índice de dificuldades relacionadas aos desenvolvedores indica que os profissionais da área são qualificados e comprometidos com as entregas, colaborando positivamente para o sucesso dos projetos.

Sendo o líder do projeto a pessoa designada pela organização para garantir o seu sucesso, a constatação de que 38\% das pessoas consideram que as dificuldades dos líderes estão influenciando o sucesso dos projetos deve ser interpretado como uma necessidade de investimento da gerência de projetos em seus funcionários para identificar pontos de melhoria.

As dificuldades relacionadas a terceiros aparecem como alto impacto nos projetos para $35 \%$ dos entrevistados. Observa-se que $50 \%$ foram neutros, o que pode indicar que não tiveram participação de terceiros em seus projetos. Considerando que apenas os que responderam como impactos baixos e altos tiveram participação de terceiros em seu projeto, o índice de impacto negativo sobe para $68 \%$. Trata-se, portanto, de uma dificuldade que merece ser investigada. 


\section{CONCLUSÕES E RECOMENDAÇÕES}

A gestão de projetos tem sido utilizada nas empresas para prover um acompanhamento eficiente dos recursos empregados e do tempo utilizado na entrega de novos produtos ou serviços. As dificuldades de implementação deste modelo surgem de diversas fontes: resistência às mudanças; estrutura organizacional inadequada; funcionários não qualificados para a função de líder de projeto; mau dimensionamento de equipes de projeto; falta de patrocínio da alta gerência, entre outros (FAJARDO; ARMANDO, 2008; ALBERTIN, 2001).

A identificação das dificuldades na gestão de projetos do Banco Comercial estudado evidenciou que a estrutura organizacional exerce um papel importante e é decisiva para proporcionar um ambiente propício para a prática da gestão de projetos.

A estrutura utilizada pela empresa é a matricial fraca, onde o líder de projeto não tem nenhum poder sobre a equipe. Os colaboradores que pertencem à equipe não estão em tempo integral dedicados ao projeto, sendo constantemente assediados por seus gerentes funcionais para assumirem outras atividades. A impossibilidade de o líder agir nestas situações, tendo sempre que recorrer ao seu superior para intervir, é um dos motivos da estrutura organizacional ter sido apontada como um problema.

Não foi apontada, na literatura pesquisada, uma estrutura organizacional ideal para a gestão de projetos. As três estruturas mais adequadas são a funcional, a por projetos e a matricial (PATAH; CARVALHO, 2002; GIDO, J; CLEMENTS, J.P., 2007). Todas elas apresentam vantagens e desvantagens e a escolha vai depender de cada empresa, que deve avaliar o processo de mudança e seu impacto. Muitas empresas adotam estruturas provisórias para atender projetos específicos. Esta estrutura pode ser criada e funcionar como um dos três tipos, sendo que a decisão de escolha é baseada no projeto que será desenvolvido, quanto à prioridade, complexidade, custo, quantidade de intervenientes, retorno sobre o investimento, entre outros fatores (PATAH; CARVALHO, 2002).

A estrutura matricial forte é a que se apresenta, atualmente, como a melhor opção para a gestão de projetos para o Banco Comercial estudado. As suas desvantagens são relacionadas principalmente à unidade de comando e disputa por 
recursos e podem ser solucionadas através de políticas claras da empresa que normatizem a questão (PATAH; CARVALHO, 2002).

A estrutura por projeto poderia ser cogitada, mas não parece adequada, pois a possibilidade de mobilidade na empresa com relação à vinculação funcional, cargo e comissões dos funcionários é bastante restrita. Para implantar este tipo de estrutura por projetos, seria necessária uma reformulação em toda a política de cargos e remuneração da empresa para que permitisse esta mobilidade. Além disso, os funcionários são especializados por função e desempenham papéis importantes em suas gerências. Uma estrutura projetizada causaria uma alteração profunda na empresa, com grande impacto na cultura organizacional, o que demandaria grande esforço para implementar a mudança.

A pesquisa mostrou que 0 apoio da alta gerência mostra-se adequado e realmente faz a diferença nos projetos. Este é um aspecto bastante positivo e deve ser reforçado dentro da organização. No relatório Extreme CHAOS da Standish Group, entre dez fatores de sucesso dos projetos o patrocínio da alta gerência aparece como o principal para a redução dos riscos do projeto (CHAOS, 2001).

Um ponto de atenção diz respeito aos aspectos relacionados aos líderes de projeto. Citando mais uma vez o relatório Extreme CHAOS da Standish Group, a experiência dos líderes de projeto aparece como o terceiro fator mais importante para a redução dos riscos do projeto (CHAOS, 2001). A capacitação dos profissionais em gestão de projetos é essencial para o crescimento desta área na Diretoria de Tecnologia da empresa. A necessidade de capacitação foi observada pelos funcionários mais experientes o que não aconteceu com os mais novos. Este é um problema que pode ser aprofundado por uma pesquisa direcionada para que seja identificado o tipo de treinamento mais adequado, se voltado para as competências técnicas ou comportamentais. Os problemas relacionados aos líderes de projeto devem ser vistos com preocupação pela Gerência de Projetos. Tratam-se dos funcionários que estão na linha de frente e, como aqueles que estão liderando os projetos e programas, são responsáveis pelos seus resultados, portanto devem ser capacitados para exercerem as suas competências de forma plena.

Segundo pesquisa da Standish Group, cada vez mais organizações estão exigindo a certificação do PMI para os seus líderes de projeto. Organizações que querem líderes na profissão de gerenciamento de projetos devem estar preparadas para investir recursos na educação, formação, pesquisa e desenvolvimento nesta 
área. A fim de proporcionar um avanço na profissão de liderança em gerenciamento de projetos deve ser criado um ambiente onde este conhecimento seja reconhecido, valorizado e recompensado. A grande tendência em Gerência de Projetos ao longo dos próximos anos será a educação dos colaboradores que não estão na área de gestão de projetos dentro de uma organização a compreender o papel do gerente de projeto para melhorar o ecossistema global de gestão de projetos e gestão de portfólios de projetos dentro da empresa. (CHAOS, 2008).

Importante recomendação apontada no relatório de tendências da Standish Group diz respeito às metodologias de gestão de projetos. O relatório mostrou que as empresas consideram importante a certificação de seus profissionais nas melhores práticas de gerenciamento de projetos com aplicação do PMBOK® do PMI. Entretanto, existe um conflito entre o processo tradicional de gerenciamento de projetos e os processos ágeis de desenvolvimento de software. A tendência deve convergir para o desenvolvimento de Gerenciamento de Projetos para Processos Ágeis. Com a unidade para métodos mais ágeis de gerenciamento de projetos, as organizações que estão se movendo nesta direção enfrentarão o problema adicional de reciclagem dos Gerentes de Projeto experientes em direção a uma abordagem mais flexível e menos estruturada (CHAOS, 2008).

Os desenvolvedores são intervenientes importantes no projeto, já que são os responsáveis pela construção da solução e entrega do produto. A pesquisa mostrou que a capacitação técnica e o comprometimento aos projetos são adequados. Observa-se que os problemas de gerenciamento dos recursos causados pela estrutura organizacional não influenciaram na dedicação dos desenvolvedores ao projeto, ou seja, uma vez que esteja definida esta alocação os analistas mostram ter capacidade e comprometimento que satisfazem às expectativas dos líderes de projeto.

As questões que tratavam da participação de terceiros nos projetos obtiveram um grande percentual de respostas no centro da escala, maior, inclusive, que o percentual dos valores significativos. Embora na análise dos resultados tenha sido proposta uma interpretação para os dados, não é seguro afirmar que a mesma seja conclusiva. Novos estudos devem ser realizados exclusivamente sobre os projetos que tenham tido a participação de terceiros para validar os resultados apresentados na análise. 
Como a pesquisa limitou-se a Gerência de Projetos, é fato que as dificuldades apresentadas tiveram como origem a visão dos líderes de projeto e seus gerentes funcionais. A mesma pesquisa deve ser aplicada nas demais Gerências da DITEC para que sejam obtidos resultados comparativos, bem como um consolidado da Diretoria.

Concluindo, o diagnóstico contribuiu para identificar dois pontos fortes que devem ser mantidos e reforçados na gestão dos projetos: o apoio da alta gerência e a competência e comprometimento dos desenvolvedores. Em contrapartida, para aumentar o índice de sucesso nos projetos, é preciso uma revisão na estrutura organizacional para aumentar o poder do líder de projeto sobre a equipe, um melhor dimensionamento das equipes de projeto, investimentos na capacitação dos líderes de projeto e uma maior aproximação dos gerentes e seus liderados para que as expectativas quanto ao seu desempenho estejam claras. 


\section{REFERÊNCIAS}

ALBERTIN, A. L; Valor Estratégico dos Projetos de Tecnologia de Informação. RAE - Revista de Administração de Empresas, Jul/Set 2001. São Paulo, v.41, n.3, pp. 42-50.

ALEXANDRE, J. W. C. et al; Análise do número de categorias da escala de Likert aplicada à gestão pela qualidade total através da teoria da resposta ao item. XXIII Encontro Nac. de Eng. de Produção - Ouro Preto, MG, Brasil, 21 a 24 de out de 2003. Disponível em:

<http://www.abepro.org.br/biblioteca/ENEGEP2003_TR0201_0741.pdf>. Acessado em: 27 nov. 2010.

BARBALHO, Sanderson César Macêdo et al. Rompendo obstáculos para a implantação de escritório de projetos em empresa de base tecnológica. Gest. Prod. [online]. 2009, vol.16, n.3, pp. 435-449. ISSN 0104-530X.

BERKUN, S. A Arte do Gerenciamento de Projetos. Tradução: Carlos Augusto Caldas de Moraes e Teresa Cristina Felix de Sousa. Editora Bookman, Porto Alegre, 2008.

BOUER, R; CARVALHO, M. M; Metodologia singular de gestão de projetos: condição suficiente para a maturidade em gestão de projetos? Depto. de Eng. Produção - Escola Politécnica da USP; Revista Produção, v. 15, n. 3, p. 347-361, Set./Dez. 2005

BRESSAN, C. L.; Mudança Organizacional: Uma Visão Gerencial. Apresentado no Seminário de Gestão de Negócios, Universidade São Francisco, Bragança Paulista-SP, 2004. Disponível em:

$<$ http://www.unifae.br/publicacoes/pdf/art_cie/art_25.pdf>. Acessado em 06 set. 2011.

CARRIERI, A. P.; LIMA, M. S.; PIMENTEL, T. D.; Resistência à Mudança Gerada pela Implementação de Sistemas de Gestão Integrada (ERP): Um Estudo de Caso. Universidade de Minas Gerais, UFMG. Revista Gestão e Planejamento, v. 8. n. 1, p. 89-105, jan./jun. 2007. Disponível em:

<http://www.revistas.unifacs.br/index.php/rgb/article/viewArticle/258>. Acessado em 06 set. 2011.

CHAOS, Report. The Trends in IT 2007/2008 Report. The Standish Group International, INC., 2008. Disponível em:

<http://standishgroup.com/sample_research/index.php>. Acessado em 18 set. 2011. 
CHAOS, Report. Extreme CHAOS Report. The Standish Group International, INC., 2001. Disponível em: <http://standishgroup.com/sample_research/index.php>. Acessado em 18 set. 2011.

CURY, Antonio. Organização e Métodos: Uma Visão Holística. Editora Atlas, 8ª . Edição, São Paulo, 2006.

DINSMORE, P. C.; SILVEIRA NETO, F. H.; Gerenciamento de Projetos e o Fator Humano:Conquistando Resultados Através das Pessoas. 2a ${ }^{a}$. Reimpressão, Editora Qualitymark, Rio de Janeiro, 2009

DOMINGUES, C. R.; BUENO, J. M.; Impacto da Resistência à Mudança na Implantação do Balanced Scored Card, Universidade São Francisco, Bragança Paulista-SP, 2005. Disponível em:

$<$ http://www.unifae.br/publicacoes/pdf/art_cie/art_21.pdf>. Acessado em 06 set. 2011.

FAJARDO, L. B. P. S; ARMANDO, E; Estruturas Organizacionais para Projetos: o Caso de Instituição Financeira. FEA-USP, 2008. Disponível em:<http://www.ead.fea.usp.br/semead/11semead/resultado/an_resumo.asp?cod_tr abalho=408>. Acessado em 15 nov. 2010.

GIAZZON, G. Orientação a Projetos: Análise Institucionalizada. Revista TI, 2005. Disponível em:<http://www.timaster.com.br/revista/artigos/main_artigo.asp?codigo=1010\&pag=2 >. Acessado em 15 nov. 2010.

GIDO, J.; CLEMENTS, J. P.; Gestão de Projetos. Editora Thomson, tradução da $3^{a}$. Edição norte-americana, São Paulo, 2007.

JACOBSEN, A. L; RODRIGUES, M. M. B.; Abordagens para lidar com a resistência humana frente a processos de mudança organizacional. Revista de Ciências da Administração-UFSC, Jan/Jun 2002. Florianópolis-SC, v.4, n.6, pp. 3949. Disponível em:

<http://www.journal.ufsc.br/index.php/adm/article/viewArticle/8107>. Acessado em: 6 set. 2011.

KERLINGER, F. N.; Metodologia da Pesquisa em Ciências Sociais. São Paulo: EPU/EDUSP, 1980.

LODI, João Bosco; A Estrutura Matricial e a Estrutura Sistêmica: Dois Novos Tipos de Organização. Revista de Administração de Empresa. FGV, 1970. 
MATTAR, F. N; Pesquisa de Marketing. Editora Atlas, 4. ed. São Paulo, 1997.

MATTAR, F. N. Pesquisa de marketing. Edição Compacta. 3.ed. São Paulo: Atlas, 2001.

PATAH, L. A; CARVALHO, M. M; Estruturas de Gerenciamento de Projetos e Competências em Equipes de Projetos. XXII Encontro Nacional de Engenharia de Produção; Curitiba-PR, 2002.

PERRELLI, H.; Gerência de Projetos: O Modelo PMBOK. Apresentação do Centro de Informática - CIN, Universidade Federal de Pernambuco, UFPE, 2004. Disponível em: <http://www.cin.ufpe.br/hermano/download/tutoriais/o-modelopmbok.pdf>. Acessado em 06 set. 2011.

PMI; Um Guia do Conhecimento em Gerenciamento de Projetos: Guia PMBOK® 2008. 4⿳亠口冋. Edição, Editado por Project Management Institute, Pennsylvania-USA 2008.

PORTAL do Banco na Internet. Disponível em:<http://www.bb.com.br/portalbb/page3,102,3527,0,0,1,6.bb?codigoMenu=1193\&c odigoNoticia=691\&codigoRet=3095\&bread=3>. Acessado em 20 nov. 2010

SILVA, E. L.; MENEZES, E. M; Metodologia da Pesquisa e Elaboração de Dissertação. Florianópolis: Laboratório de Ensino a Distância da UFSC, 2001.

SOARES, A. J.; TIBO, M; Tradução Livre do PMBOK. PMIMG, 2000. Disponível em: <http://www.dfa.ensino.eb.br/peg/PMBok/pmbok1_introducao.pdf>. Acessado em 04 set. 2011.

TORREÃO, Paula G. B. Coelho. Project Management Knowledge Learning Environment: Ambiente Inteligente de Aprendizado para Educação em Gerenciamento de Projetos. Dissertação de Mestrado - Centro de Informática UFPE. Março, 2005.Disponível em:<http://php.cin.ufpe.br/ pmk/hp/publicacoes/dissertacao/PMK-VICTORDissertation.PDF >. Acesso em 24 abr. 2010.

ZANELLA, L. C. H. Metodologia da Pesquisa. Florianópolis-SC, SEaD/UFSC, 2006.

ZANCHIN, R. A Gestão de Tesouraria e sua Interface com as Estratégias Financeiras das Empresas de Pequeno Porte do Setor Metal-mecânico de Caxias do Sul. Dissertação de Mestrado. Universidade Federal do Rio Grande do 
Sul, 2002. Disponível em: < http://pt.scribd.com/doc/61633595/25/O-Calculo-do-ErroAmostral> Acesso em 10 set. 2011. 


\section{ANEXOS}

ANEXO 1 - Proposta de questionário:

\begin{tabular}{|c|c|}
\hline ASSUNTOS & AFIRMATIVAS \\
\hline \multicolumn{2}{|l|}{$\begin{array}{l}\text { Problemas organizacionais e } \\
\text { da alta gerência }\end{array}$} \\
\hline falta de apoio da alta gerência & $\begin{array}{l}\text { O apoio da alta gerência foi determinante nos projetos em } \\
\text { que participei. }\end{array}$ \\
\hline $\begin{array}{l}\text { estrutura organizacional inadequada } \\
\text { para trabalhar com projetos }\end{array}$ & $\begin{array}{l}\text { A estrutura organizacional da DITEC colabora para o } \\
\text { sucesso dos projetos }\end{array}$ \\
\hline $\begin{array}{l}\text { dimensionamento errado do grupo de } \\
\text { projeto }\end{array}$ & $\begin{array}{l}\text { O dimensionamento das equipes de projeto é adequado } \\
\text { para a sua realização }\end{array}$ \\
\hline $\begin{array}{l}\text { falta de comprometimento das } \\
\text { pessoas envolvidas }\end{array}$ & $\begin{array}{l}\text { As pessoas envolvidas com o projeto estão } \\
\text { comprometidas com as suas atividades }\end{array}$ \\
\hline \multicolumn{2}{|l|}{$\begin{array}{l}\text { Problemas relacionados aos } \\
\text { líderes de projeto }\end{array}$} \\
\hline falta de agilidade e pró-atividade & $\begin{array}{l}\text { O líder de projeto age com rapidez e pró-atividade na } \\
\text { solução dos problemas }\end{array}$ \\
\hline falta de planejamento adequado & $\begin{array}{l}\text { Os planejamentos tem se mostrado adequados, sofrendo } \\
\text { mínimas alterações durante o ciclo de vida dos projetos }\end{array}$ \\
\hline $\begin{array}{l}\text { Capacitação dos gerentes de projeto } \\
\text { insuficiente }\end{array}$ & $\begin{array}{l}\text { Os líderes de projeto possuem a capacitação necessária } \\
\text { para exercer as suas atribuições }\end{array}$ \\
\hline $\begin{array}{l}\text { acompanhamento e controle } \\
\text { ineficiente }\end{array}$ & $\begin{array}{l}\text { Os projetos são acompanhados eficientemente, com } \\
\text { relatórios de controle e gerenciamento de riscos }\end{array}$ \\
\hline \multicolumn{2}{|l|}{$\begin{array}{l}\text { Problemas relacionados aos } \\
\text { desenvolvedores }\end{array}$} \\
\hline falta de agilidade e pró-atividade & $\begin{array}{l}\text { Os Responsáveis Técnicos demonstram pró-atividade e } \\
\text { agilidade na solução dos problemas }\end{array}$ \\
\hline $\begin{array}{l}\text { falta de experiência dos integrantes do } \\
\text { projeto }\end{array}$ & $\begin{array}{l}\text { O nível de conhecimento e experiência dos RT são } \\
\text { adequados para o desenvolvimento de suas atividades }\end{array}$ \\
\hline qualidade das tarefas técnicas & $\begin{array}{l}\text { As entregas dos desenvolvedores possuem o nível de } \\
\text { qualidade esperada }\end{array}$ \\
\hline
\end{tabular}




\section{Problemas relacionados a} terceiros

A dependência de entidades externas tem comprometido

grande dependência de terceiros os projetos em que as mesmas participam

falta de clareza na definição de

O contrato com fornecedores tem a clareza necessára contrato com fornecedores para um gerenciamento de aquisições com qualidade

problemas de logística

Projetos que envolvem logísticas, tais como transporte de materiais, sofrem com problemas de execução 
ANEXO 2 - Planilha com respostas da pesquisa

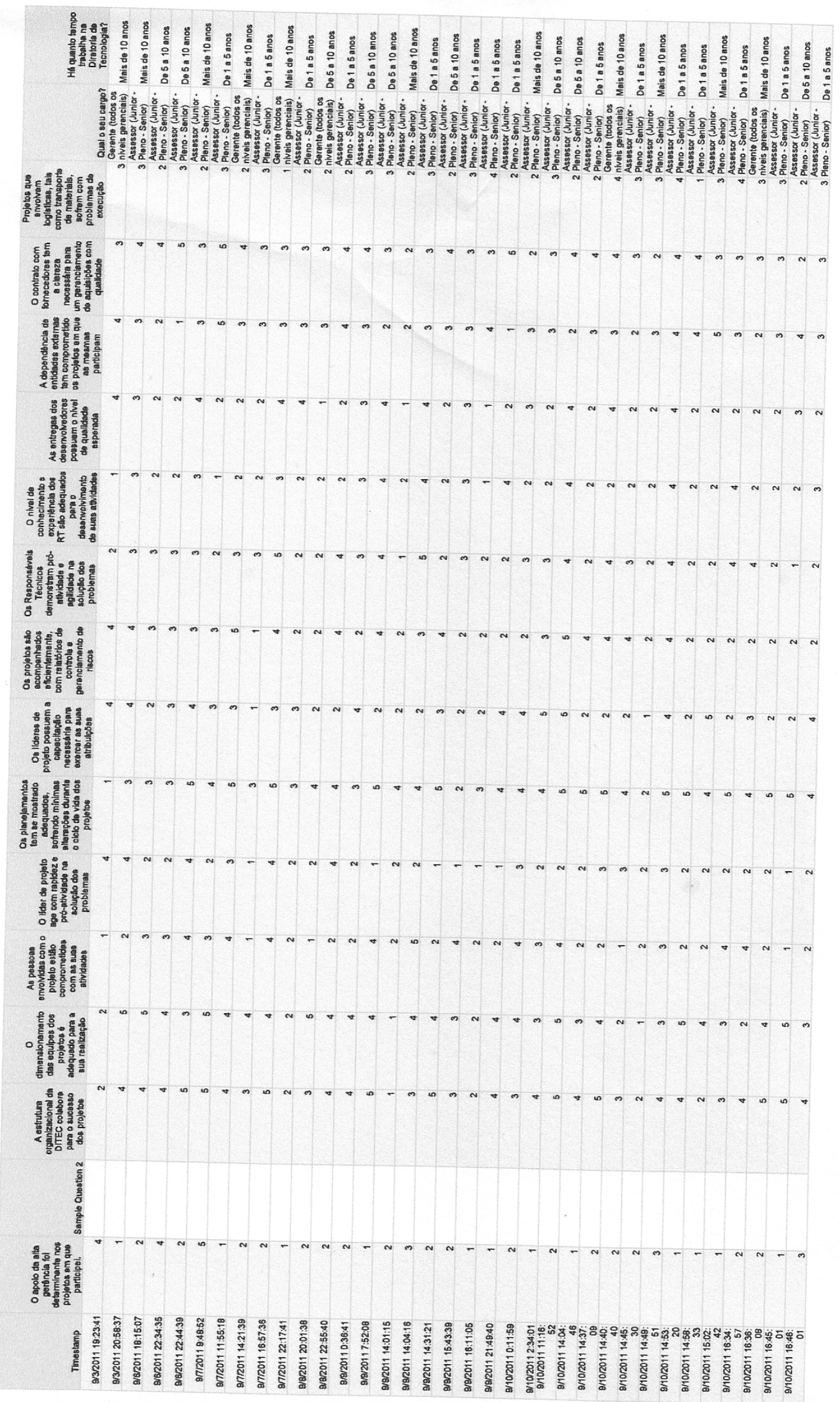


ANEXO 3 - Questionário de pesquisa

\section{Gestão de Projetos}

Colega, preciso de sua ajuda na dedicação de alguns minutos para responder às questões abaixo. Trata-se de uma pesquisa com os funcionários da GPP para diagnosticar a percepção sobre a gestão dos projetos na Diretoria de Tecnologia da empresa.

A pesquisa é parte do Trabalho de Conclusão de Curso de Administração necessário para obtenção do grau de bacharelado junto à Universidade de Brasília.

Nem você nem a empresa serão identificados no trabalho.

Muito obrigado.

* Required

\section{Pergunt $\square$ s inici $\square$ is}

Qu $\square$ o seu c $\square$ rgo? *

Gerente (todos os niveis gerenciais)

Assessor (Junior - Pleno - Senior)

Há qu $\square$ nto tempo $\operatorname{tr} \square \mathbf{b} \square \mathbf{h} \square \mathbf{n} \square$ Diretori $\square$ de Tecnologi $\square$ ? *
Menos de 1 ano
De 1 a 5 anos
De 5 a 10 anos
Mais de 10 anos

\section{Orient $\sqsubset$ ções $\mathbf{p} \square \square$ o preenchimeto}

A resposta às questões corresponde à escolha de um valor em um intervalo de 1 a 5 , sendo que: o 1 representa concordância total com a afirmativa, o 2 concordância em parte, o 3 neutro, o 4 discordância parcial e o 5 discordância total.

O $\square$ poio d $\square \square \mathbf{t} \square$ gerênci $\square$ foi determin $\square$ nte nos projetos em que p $\square$ rticipei. * Considere alta gerência como Gerente Executivo ou maior.

$$
\begin{array}{lllll}
1 & 2 & 3 & 4 & 5
\end{array}
$$

Concordo Totalmente $\odot \odot \odot \bigcirc$ Discordo Totalmente

A estrutur $\square$ org $\square$ niz $\square$ cion $\square \mathrm{d} \square$ DITEC col $\square$ bor $\square$ p $\square \square$ o sucesso dos projetos *

$$
\begin{array}{lllll}
1 & 2 & 3 & 4 & 5
\end{array}
$$

Concordo Totalmente $\bigcirc \odot \odot \bigcirc$ Discordo Totalmente

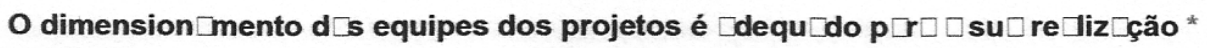

$$
\begin{array}{lllll}
1 & 2 & 3 & 4 & 5
\end{array}
$$

Concordo Totalmente $\odot \odot \odot$ Discordo Totalmente 
As pessoas envolvidas com o projeto estão comprometidas com as suas atividades *

$\begin{array}{lllll}1 & 2 & 3 & 4 & 5\end{array}$

Concordo Totalmente $\odot \odot \odot \bigcirc$ Discordo Totalmente

O líder de projeto age com rapidez e pró-atividade na solução dos problemas *

$$
\begin{array}{lllll}
1 & 2 & 3 & 4 & 5
\end{array}
$$

Concordo Totalmente $\odot \odot \odot \bigcirc$ Discordo Totalmente

Os planejamentos tem se mostrado adequados, sofrendo mínimas alterações durante o ciclo de vida dos projetos*

$\begin{array}{lllll}1 & 2 & 3 & 4 & 5\end{array}$

Concordo Totalmente $\bigcirc \bigcirc \bigcirc \bigcirc$ Discordo Totalmente

Os líderes de projeto possuem a capacitação necessária para exercer as suas atribuições *

$$
\begin{array}{lllll}
1 & 2 & 3 & 4 & 5
\end{array}
$$

Concordo Totalmente $\bigcirc \bigcirc \bigcirc \bigcirc$ Discordo Totalmente

Os projetos são acompanhados eficientemente, com relatórios de controle e gerenciamento de riscos *

$$
\begin{array}{lllll}
1 & 2 & 3 & 4 & 5
\end{array}
$$

Concordo Totalmente $\odot \odot \bigcirc \bigcirc$ Discordo Totalmente

Os Responsáveis Técnicos demonstram pró-atividade e agilidade na solução dos problemas *

$\begin{array}{lllll}1 & 2 & 3 & 4 & 5\end{array}$

Concordo Totalmente $\odot \odot \bigcirc \bigcirc$ Discordo Totalmente

O nível de conhecimento e experiência dos RT são adequados para o desenvolvimento de suas atividades *

$$
\begin{array}{lllll}
1 & 2 & 3 & 4 & 5
\end{array}
$$

Concordo Totalmente $\bigcirc \bigcirc$ Discordo Totalmente

As entregas dos desenvolvedores possuem o nivel de qualidade esperada *

$$
\begin{array}{lllll}
1 & 2 & 3 & 4 & 5
\end{array}
$$

Concordo Totalmente $\bigcirc \bigcirc \bigcirc \bigcirc$ Discordo Totalmente

A dependência de entidades externas tem comprometido os projetos em que as mesmas participam *

$$
\begin{array}{lllll}
1 & 2 & 3 & 4 & 5
\end{array}
$$

Concordo Totalmente $\bigcirc \bigcirc$ Discordo Totalmente 
O contrato com fornecedores tem a clareza necessára para um gerenciamento de aquisições com qualidade *

$\begin{array}{lllll}1 & 2 & 3 & 4 & 5\end{array}$

Concordo Totalmente $\bigcirc \bigcirc \bigcirc$ Discordo Totalmente

Projetos que envolvem logísticas, tais como transporte de materiais, sofrem com problemas de execução *

$\begin{array}{lllll}1 & 2 & 3 & 4 & 5\end{array}$

Concordo Totalmente $\odot \odot \odot \odot$ Discordo Totalmente

\section{Submit}

Powered by Google Docs

Report Abuse - Terms of Service - Additional Terms 
ANEXO 4 - Gráficos de pesquisa

$35_{\text {responses }}$

Summary see complete responses

Perguntas iniciais

Qual o seu cargo?

Gerente (todos os niveis gerenciais) $617 \%$

Pleno - Senion) [29]

Assessor (Junior - Pleno - Senior)

$2983 \%$

Há quanto tempo trabalha na Diretoria de Tecnologia?

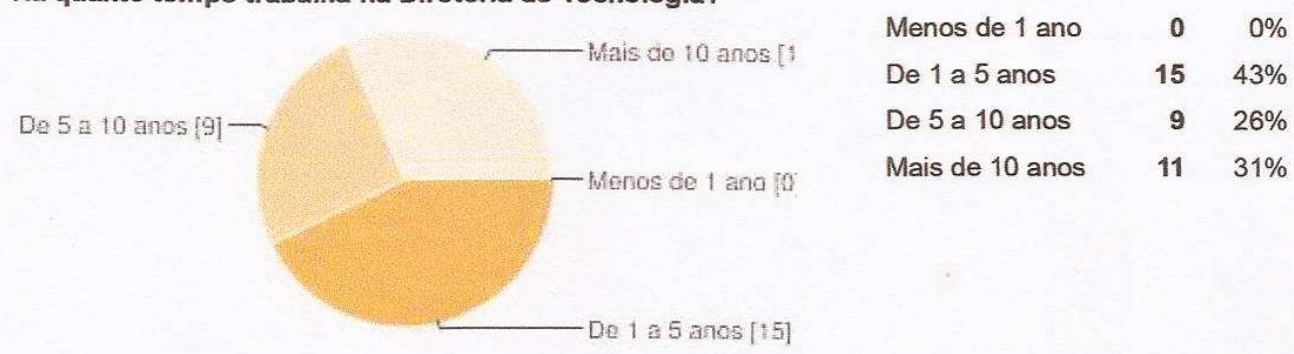

\section{Orientações para o preenchimeto}

A resposta às questões corresponde à escolha de um valor em um intervalo de 1 a 5 , sendo que: o 1 representa concordância total com a afirmativa, o 2 concordância em parte, o 3 neutro, $\circ 4$ discordância parcial e o 5 discordância total.

O apoio da alta gerência foi determinante nos projetos em que participei. 
stão de Projetos ] - Google Docs

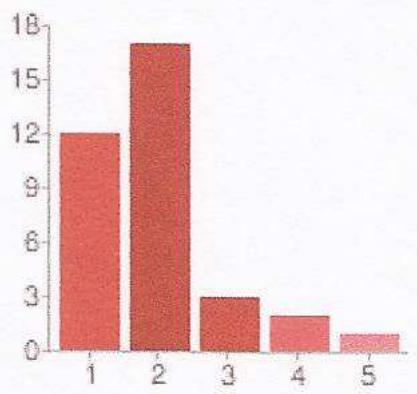

Concordo TotalmenteDiscordo Totalmente https://docs.google.com/spreadsheet/gform?key=0.

$\begin{array}{lrr}1 \text {-Concordo Totalmente } & 12 & 34 \% \\ 2 & 17 & 49 \% \\ 3 & 3 & 9 \% \\ 4 & 2 & 6 \% \\ 5 \text {-Discordo Totalmente } & 1 & 3 \%\end{array}$

A estrutura organizacional da DITEC colabora para o sucesso dos projetos

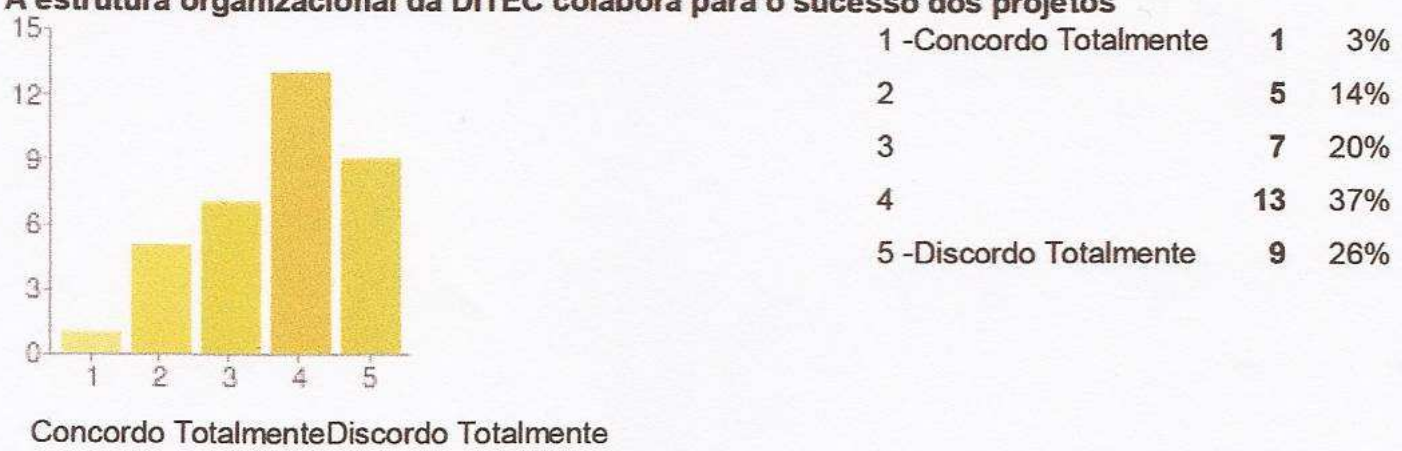

O dimensionamento das equipes dos projetos é adequado para a sua realização

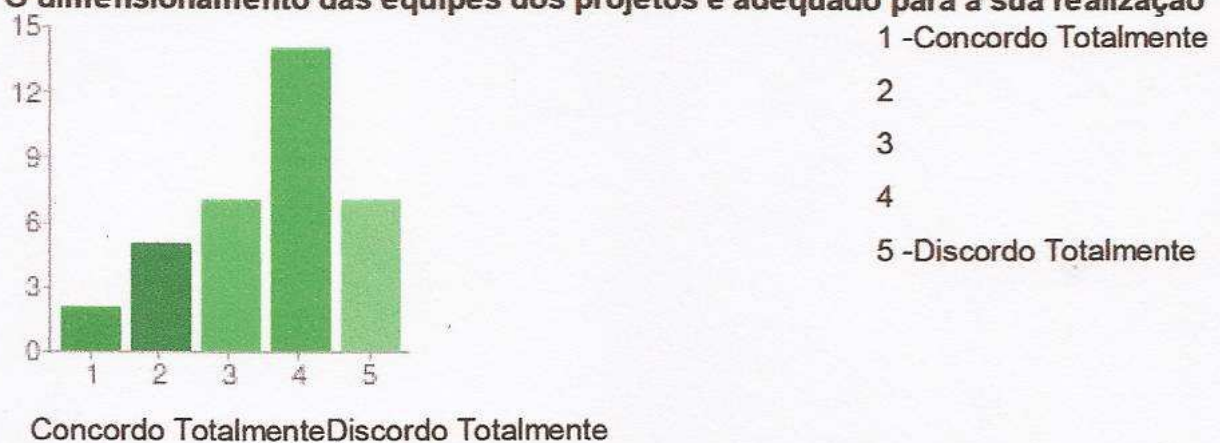

$26 \%$

$514 \%$

$720 \%$

$1440 \%$

$720 \%$

As pessoas envolvidas com o projeto estão comprometidas com as suas atividades 
1 - [ Gestão de Projetos ] - Google Docs

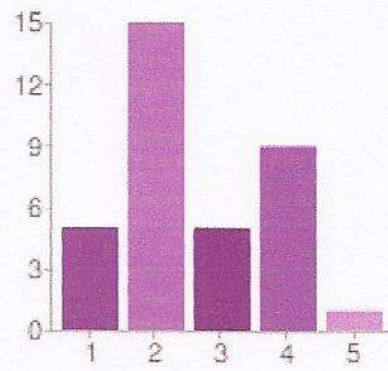

Concordo TotalmenteDiscordo Totalmente https://docs.google.com/spreadsheet/gform?key=0

$\begin{array}{lrr}1 \text {-Concordo Totalmente } & 5 & 14 \% \\ 2 & 15 & 43 \% \\ 3 & 5 & 14 \% \\ 4 & 9 & 26 \% \\ 5 \text {-Discordo Totalmente } & 1 & 3 \%\end{array}$

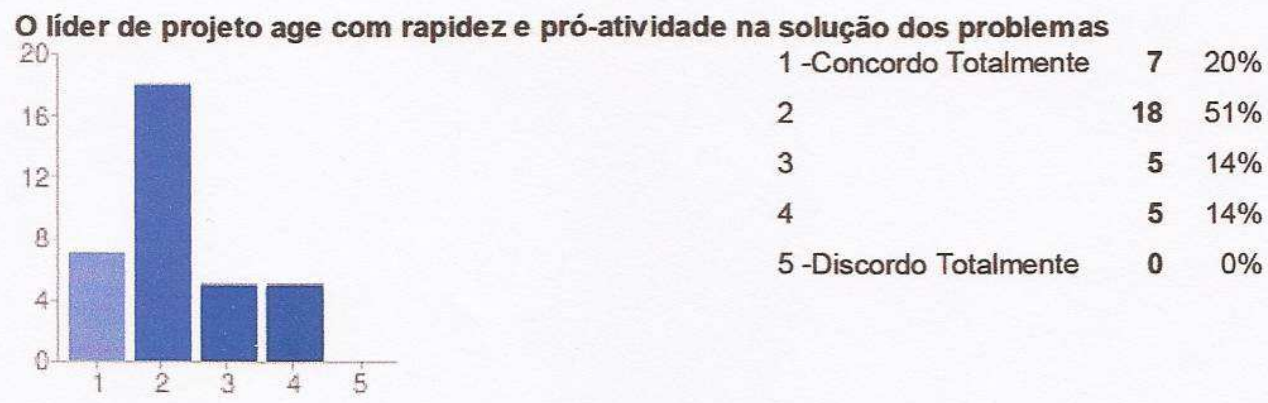

Concordo TotalmenteDiscordo Totalmente

Os planejamentos tem se mostrado adequados, sofrendo mínimas alterações durante o ciclo de vida dos projetos

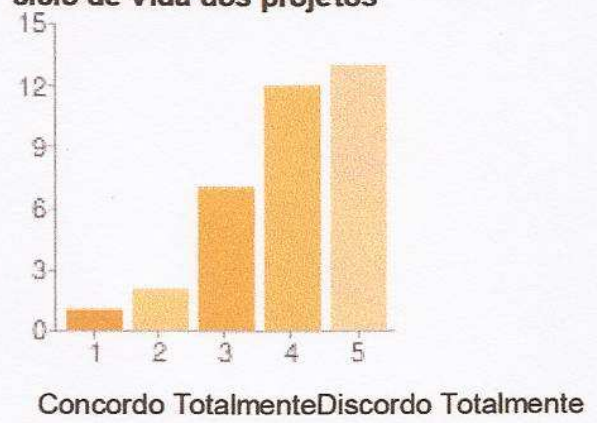

$\begin{array}{lrr}1 \text {-Concordo Totalmente } & 1 & 3 \% \\ 2 & 2 & 6 \% \\ 3 & 7 & 20 \% \\ 4 & 12 & 34 \% \\ 5 \text {-Discordo Totalmente } & 13 & 37 \%\end{array}$


1- [ Gestão de Projetos ] - Google Docs

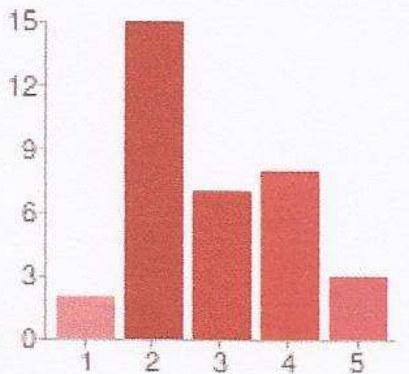

Concordo TotalmenteDiscordo Totalmente https://docs.google.com/spreadsheet/gform?key:

$\begin{array}{lrr}1 \text {-Concordo Totalmente } & 2 & 6 \% \\ 2 & 15 & 43 \% \\ 3 & 7 & 20 \% \\ 4 & 8 & 23 \% \\ 5 \text {-Discordo Totalmente } & 3 & 9 \%\end{array}$

Os projetos são acompanhados eficientemente, com relatórios de controle e gerenciamento de riscos

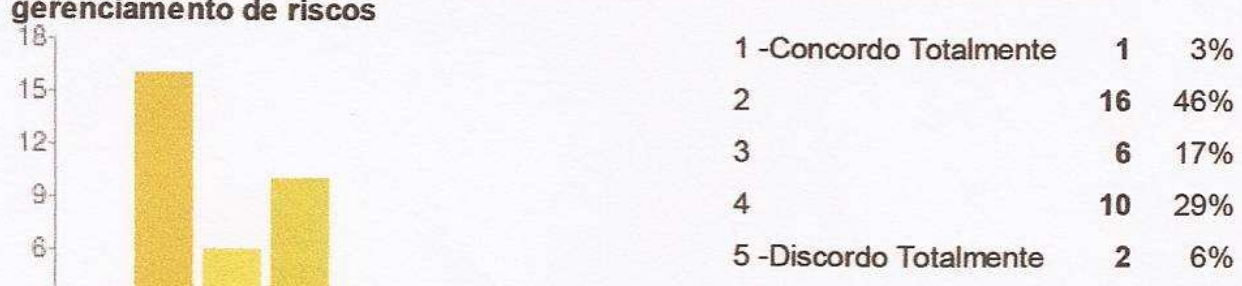

Os Responsáveis Técnicos demonstram pró-atividade e agilidade na solução dos problemas

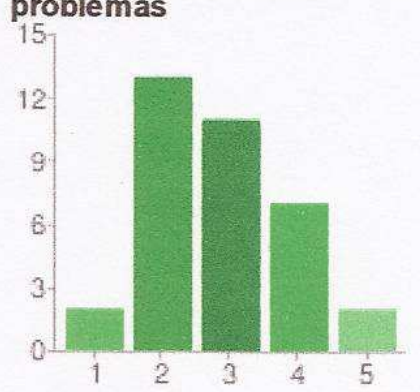

$\begin{array}{lrr}1 \text {-Concordo Totalmente } & 2 & 6 \% \\ 2 & 13 & 37 \% \\ 3 & 11 & 31 \% \\ 4 & 7 & 20 \% \\ 5 \text {-Discordo Totalmente } & 2 & 6 \%\end{array}$

Concordo TotalmenteDiscordo Totalmente 


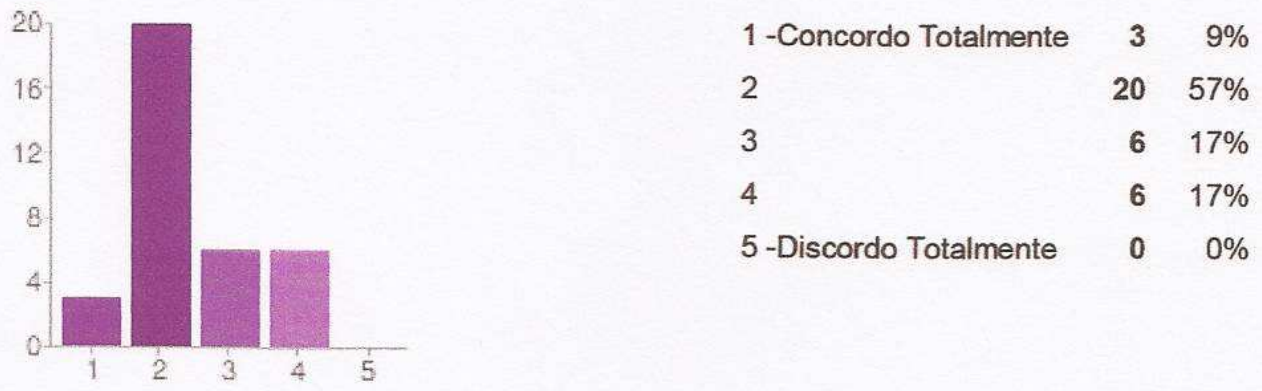

Concordo TotalmenteDiscordo Totalmente

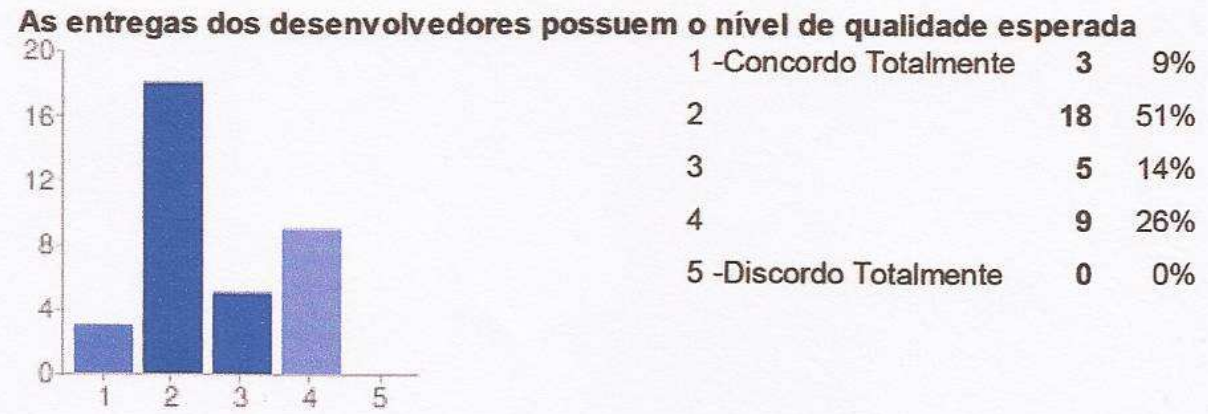

Concordo TotalmenteDiscordo Totalmente

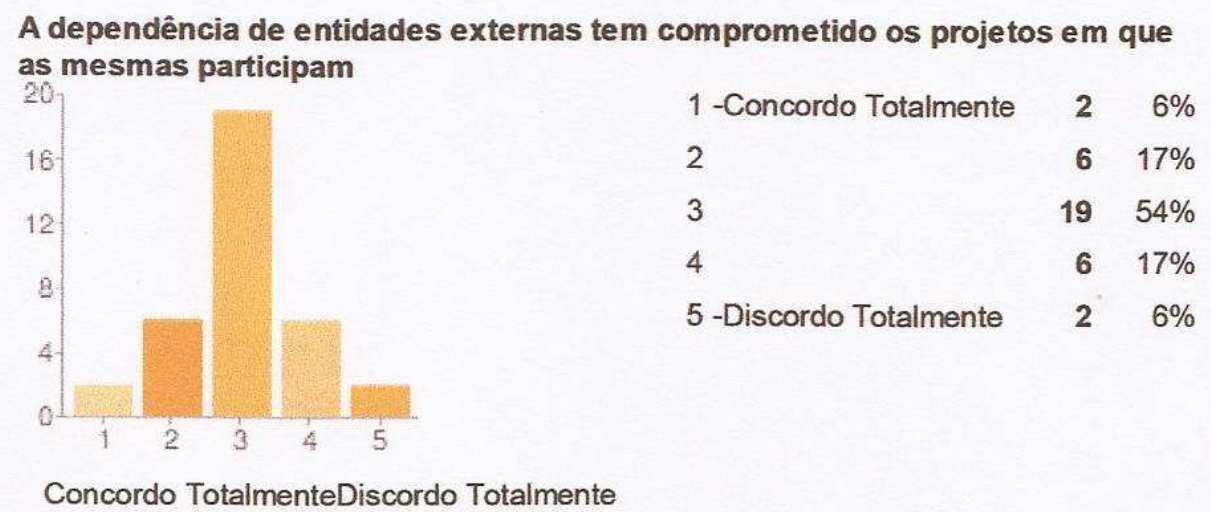

O contrato com fornecedores tem a clareza necessára para um gerenciamento de aquisições com qualidade 


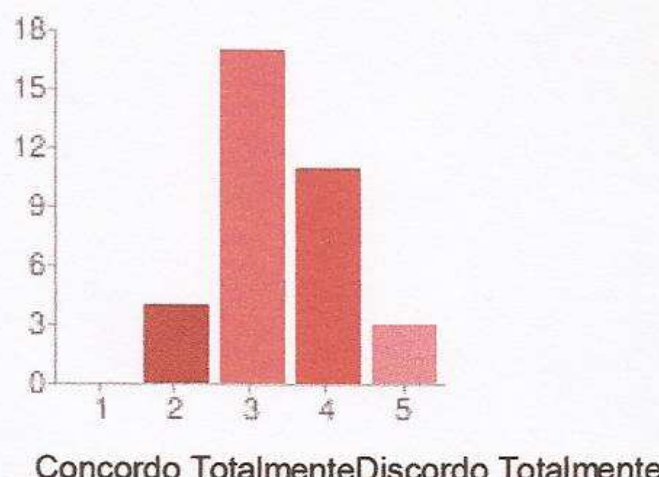

$\begin{array}{lrr}1 \text {-Concordo Totalmente } & 0 & 0 \% \\ 2 & 4 & 11 \% \\ 3 & 17 & 49 \% \\ 4 & 11 & 31 \% \\ 5 \text {-Discordo Totalmente } & 3 & 9 \%\end{array}$

Projetos que envolvem logísticas, tais como transporte de materiais, sofrem com problemas de execução

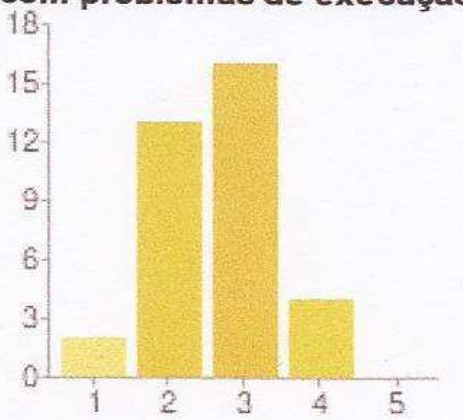

1 -Concordo Totalmente $2 \quad 6 \%$

2

$13 \quad 37 \%$

3

$1646 \%$

4

$411 \%$

5 -Discordo Totalmente

$0 \quad 0 \%$

Concordo TotalmenteDiscordo Totalmente

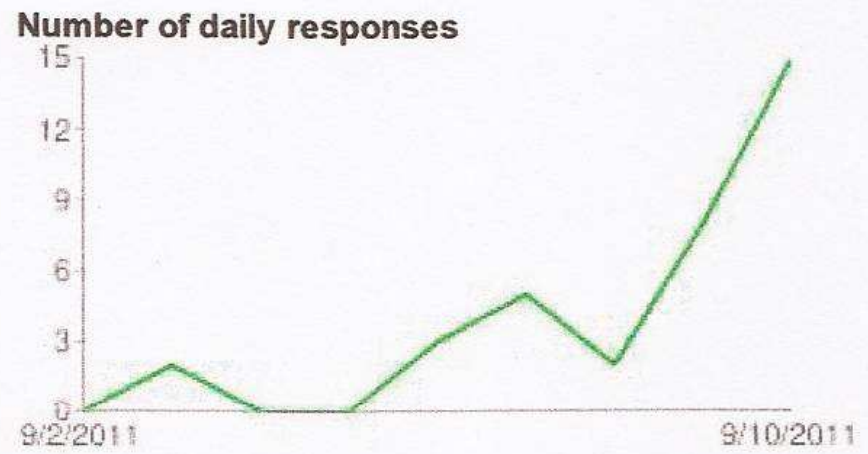


ANEXO 5 - Planilhas de cálculo

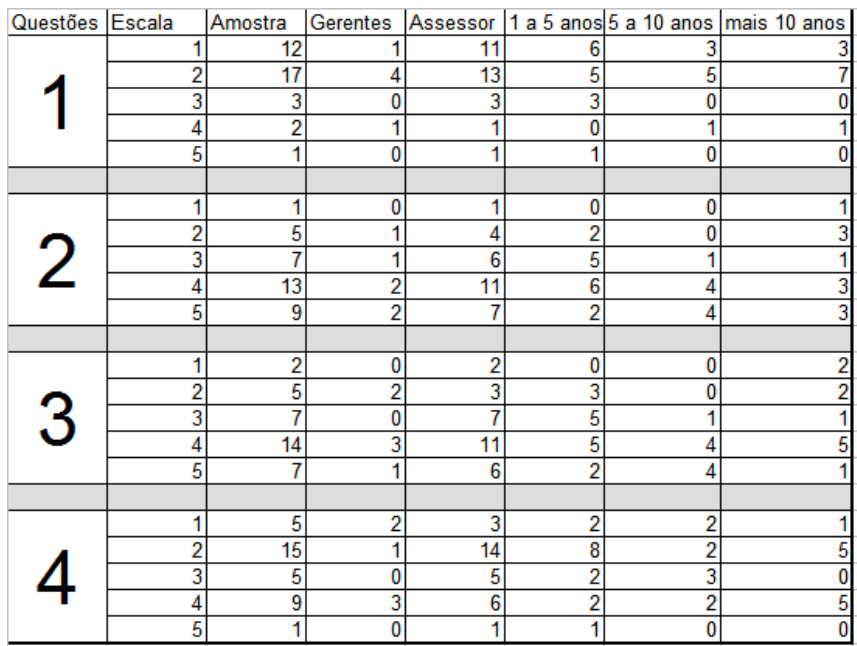

\begin{tabular}{|l|r|r|r|r|r|}
\hline Amostra & Gerentes & Assessor & 1 a 5 anos 5 a 10 ano & mais 10 anos \\
\hline $34 \%$ & $17 \%$ & $33 \%$ & $40 \%$ &
\end{tabular}

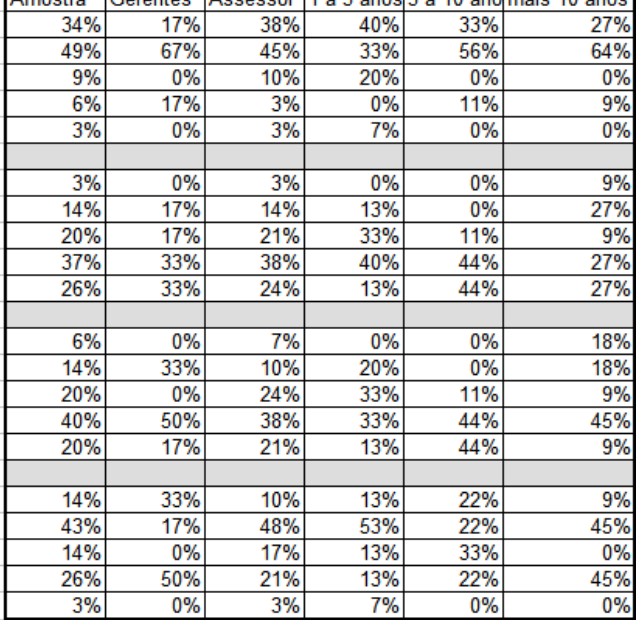

Agrupamento das 4 questões por itens da escala - quantidade

\begin{tabular}{|l|l|l|l|l|l|l|}
\hline Problema & Escala & Amostra & Gerentes & Assessor & 1 a 5 anos 5 a 10 anos & mais 10 anos \\
\hline
\end{tabular} organizaci

onais e

da alta

gerência
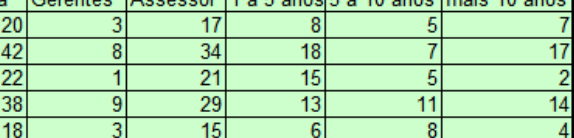

Total

$24 \mid$

60

36

44

\begin{tabular}{|c|c|c|c|c|c|}
\hline \multicolumn{6}{|c|}{ Agrupamento das 4 questões por itens da escala - percentual } \\
\hline Amostra & Gerentes & Assessor & 1 a 5 anos & 5 a 10 ano & mais 10 anos \\
\hline $14 \%$ & $13 \%$ & $15 \%$ & $13 \%$ & $14 \%$ & $16 \%$ \\
\hline $30 \%$ & $33 \%$ & $29 \%$ & $30 \%$ & $19 \%$ & $39 \%$ \\
\hline $16 \%$ & $4 \%$ & $18 \%$ & $25 \%$ & $14 \%$ & $5 \%$ \\
\hline $27 \%$ & $38 \%$ & $25 \%$ & $22 \%$ & $31 \%$ & $32 \%$ \\
\hline $13 \%$ & $13 \%$ & $13 \%$ & $10 \%$ & $22 \%$ & $9^{\circ}$ \\
\hline \multicolumn{6}{|c|}{ Totalizando escalas $1+2$ e $4+5$} \\
\hline $44 \%$ & $46 \%$ & $44 \%$ & $43 \%$ & $33 \%$ & $55 \%$ \\
\hline $16 \%$ & $4 \%$ & $18 \%$ & $25 \%$ & $14 \%$ & $5 \%$ \\
\hline $40 \%$ & $50 \%$ & $38 \%$ & $32 \%$ & $53 \%$ & $\overline{41}$ \\
\hline
\end{tabular}

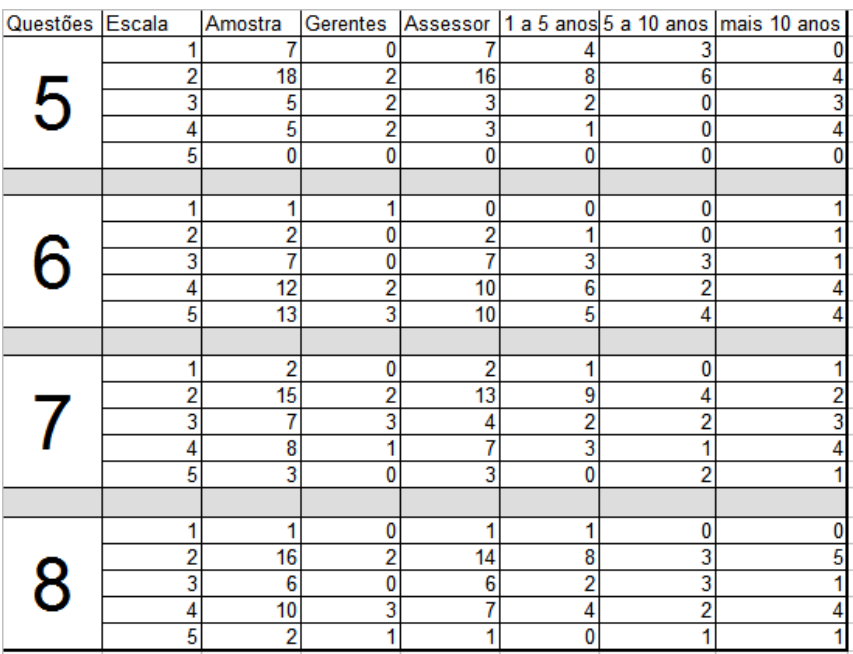

\begin{tabular}{|l|l|l|l|l|l|} 
Amostra & Gerentes & Assessor & 1 a 5 anos 5 a 10 ano mais 10 anos \\
\hline
\end{tabular}

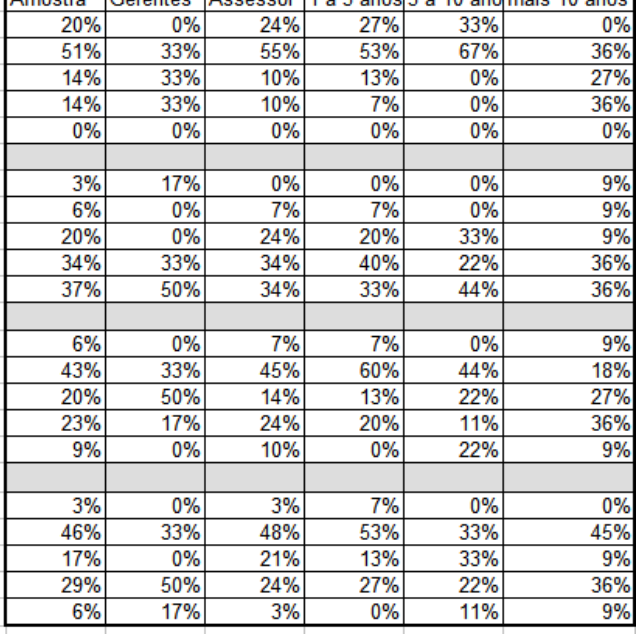

Agrupamento das 4 questỗes por itens da escala - quantidade

\begin{tabular}{l|l|l|l|l|l|l|} 
& & \\
\hline
\end{tabular}

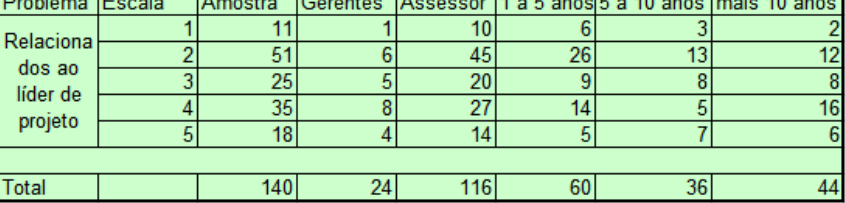

Agrupamento das 4 questỗes por itens da escala - percentual

Amostra Gerentes Assessor 1 a 5 anos 5 a 10 ano mais 10 anos

\begin{tabular}{|c|c|c|c|c|c|}
\hline & & & & & \\
\hline $8 \%$ & $4 \%$ & $9 \%$ & $10 \%$ & $8 \%$ & $5 \%$ \\
\hline $36 \%$ & $25 \%$ & $39 \%$ & $43 \%$ & $36 \%$ & $27 \%$ \\
\hline $18 \%$ & $21 \%$ & $17 \%$ & $15 \%$ & $22 \%$ & $18 \%$ \\
\hline $25 \%$ & $33 \%$ & $23 \%$ & $23 \%$ & $14 \%$ & $36 \%$ \\
\hline $13 \%$ & $17 \%$ & $12 \%$ & $8 \%$ & $19 \%$ & $14 \%$ \\
\hline \multicolumn{6}{|c|}{ Totalizando escalas $1+2$ e $4+5$} \\
\hline $44 \%$ & $29 \%$ & $47 \%$ & $53 \%$ & $44 \%$ & 32 \\
\hline $18 \%$ & $21 \%$ & $17 \%$ & $15 \%$ & $22 \%$ & $18 \%$ \\
\hline $38 \%$ & $50 \%$ & $35 \%$ & $32 \%$ & $33 \%$ & 50 \\
\hline
\end{tabular}



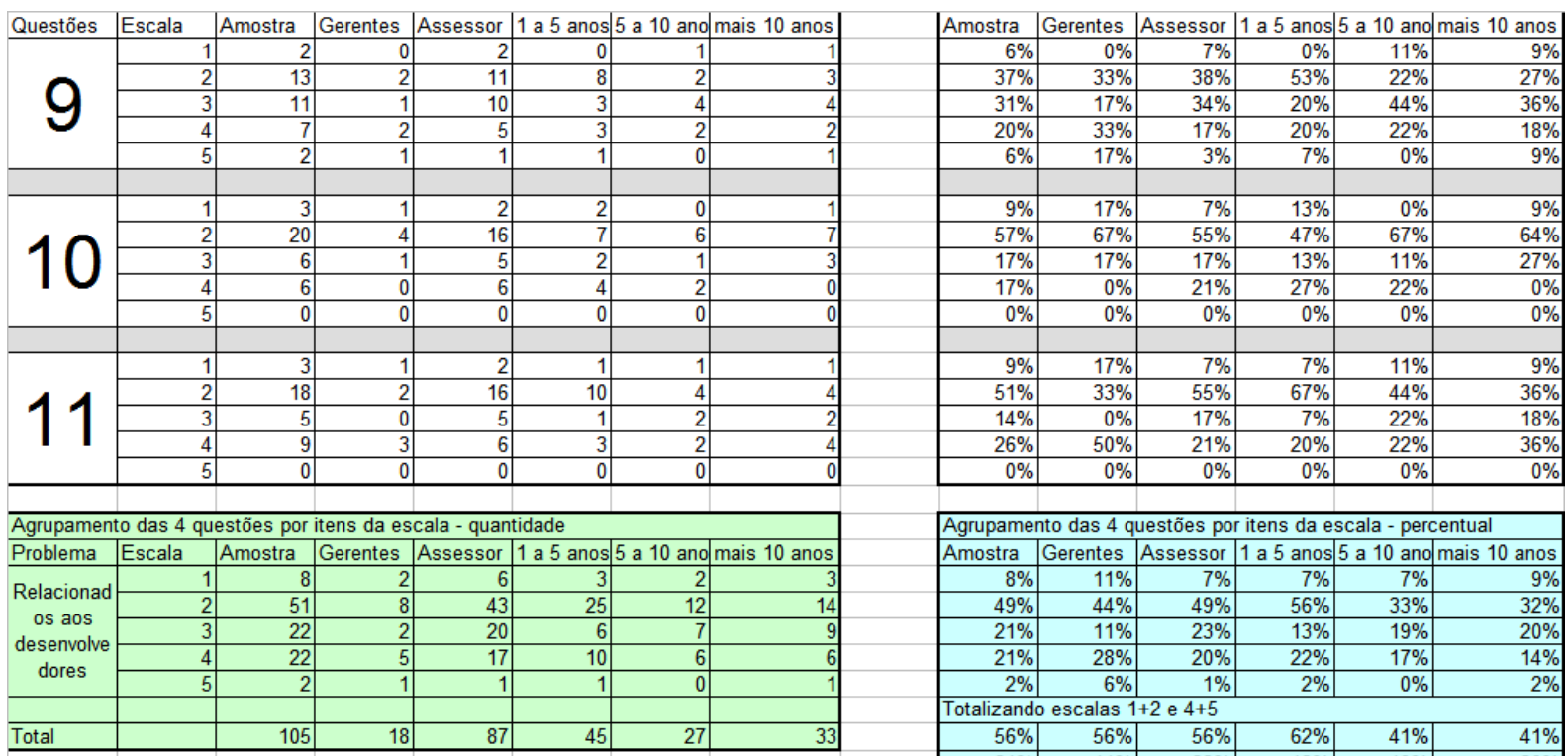

Agrupamento das 4 questôes por itens da escala - percentual \begin{tabular}{|r|r|r|r|r|r|}
\hline Amostra & Gerentes & Assessor & 1 a 5 anos & 5 a 10 ano & mais 10 anos \\
\hline $8 \%$ & $11 \%$ & $7 \%$ & $7 \%$ & $7 \%$ & $9 \%$ \\
\hline
\end{tabular}

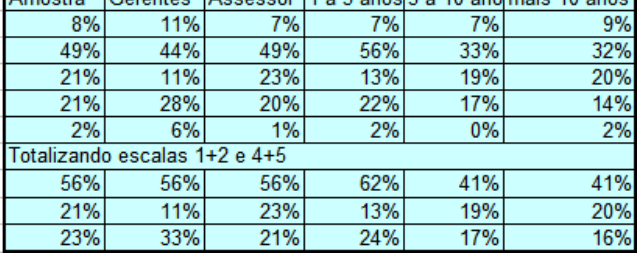

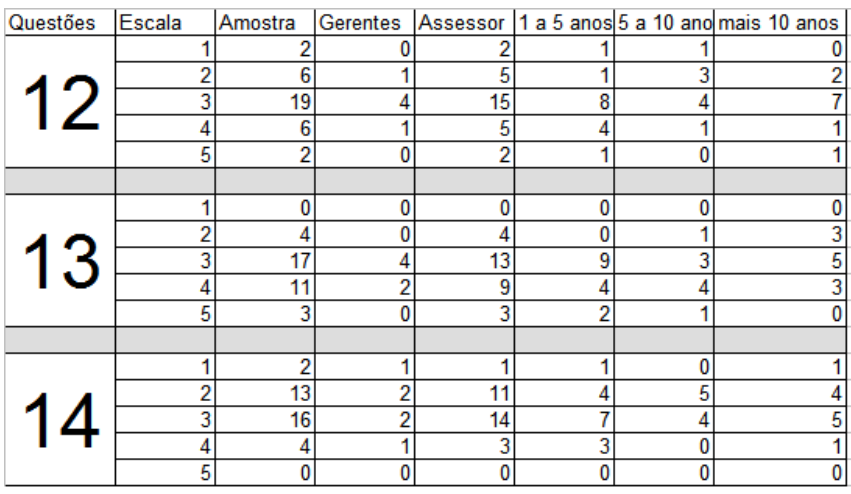

\begin{tabular}{|r|r|r|r|r|r|} 
Amostra & Gerentes & Assessor & 1 a 5 anos & 5 a 10 ano & mais 10 anos \\
\hline $6 \%$ & $0 \%$ & $7 \%$ & $7 \%$ & $11 \%$ & $0 \%$ \\
\hline $17 \%$ & $17 \%$ & $17 \%$ & $7 \%$ & $33 \%$ & $18 \%$ \\
\hline $54 \%$ & $67 \%$ & $52 \%$ & $53 \%$ & $44 \%$ & $64 \%$ \\
\hline $17 \%$ & $17 \%$ & $17 \%$ & $27 \%$ & $11 \%$ & $9 \%$ \\
\hline $6 \%$ & $0 \%$ & $7 \%$ & $7 \%$ & $0 \%$ & $9 \%$ \\
\hline & & & & & \\
\hline $0 \%$ & $0 \%$ & $0 \%$ & $0 \%$ & $0 \%$ & $0 \%$ \\
\hline $11 \%$ & $0 \%$ & $14 \%$ & $0 \%$ & $11 \%$ & $27 \%$ \\
\hline $49 \%$ & $67 \%$ & $45 \%$ & $60 \%$ & $33 \%$ & $45 \%$ \\
\hline $31 \%$ & $33 \%$ & $31 \%$ & $27 \%$ & $44 \%$ & $27 \%$ \\
\hline $9 \%$ & $0 \%$ & $10 \%$ & $13 \%$ & $11 \%$ & $0 \%$ \\
\hline & & & & & \\
\hline $6 \%$ & $17 \%$ & $3 \%$ & $7 \%$ & $0 \%$ & $9 \%$ \\
\hline $37 \%$ & $33 \%$ & $38 \%$ & $27 \%$ & $56 \%$ & $36 \%$ \\
\hline $46 \%$ & $33 \%$ & $48 \%$ & $47 \%$ & $44 \%$ & $45 \%$ \\
\hline $11 \%$ & $17 \%$ & $10 \%$ & $20 \%$ & $0 \%$ & $9 \%$ \\
\hline $0 \%$ & $0 \%$ & $0 \%$ & $0 \%$ & $0 \%$ & $0 \%$ \\
\hline
\end{tabular}


Invertendo respostas escalas 1 com 5 e 2 com 4 nas questöes 12 e 14
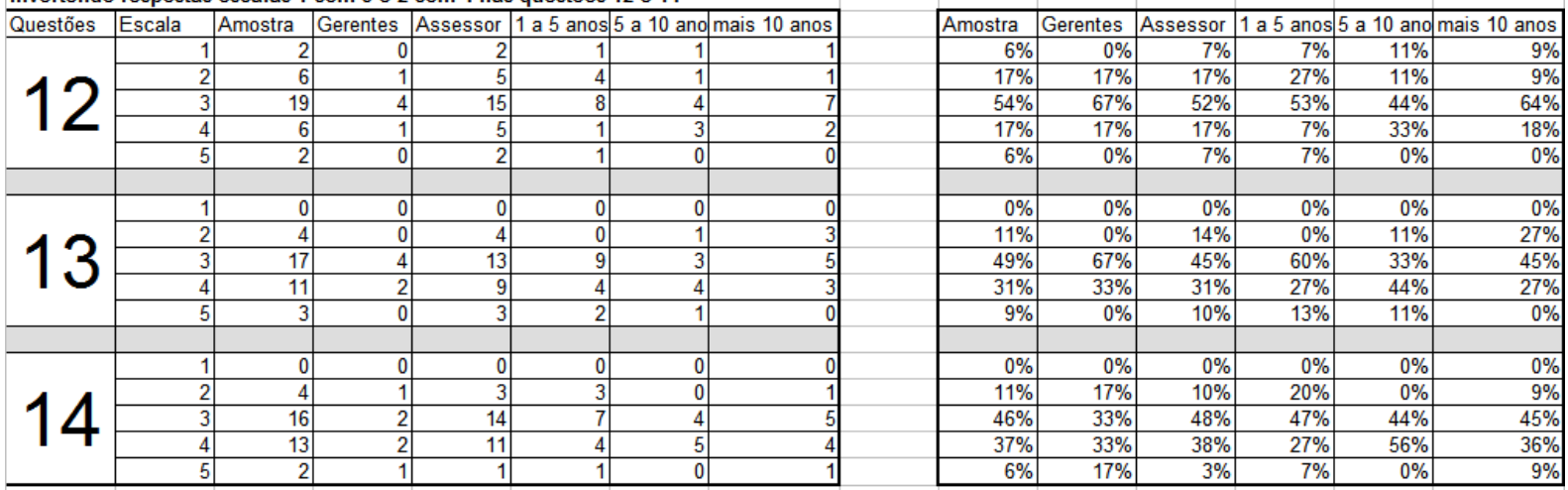

Agrupamento das 4 questões por itens da escala - quantidade

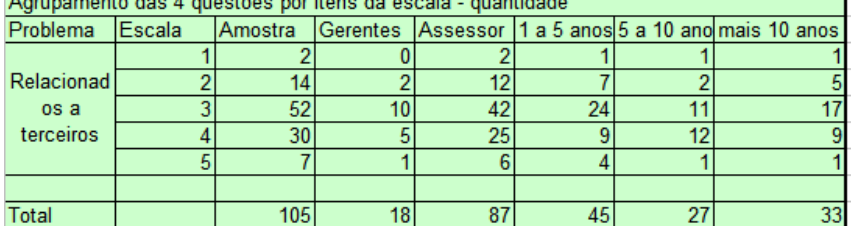

Agrupamento das 4 questões por itens da escala - percentual \begin{tabular}{|l|l|l|l|l|l|}
\hline Amostra & Gerentes & Assessor & 1 a 5 anos & 5 a 10 ano & mais 10 anos \\
\hline
\end{tabular}

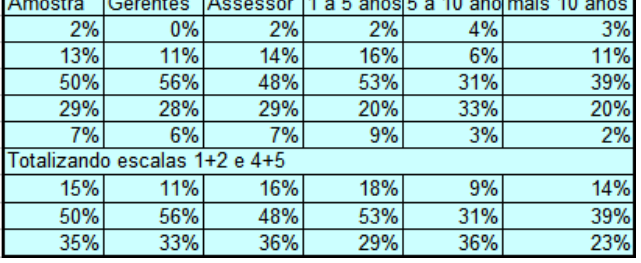

